Prepared in cooperation with the National Park Service, Glen Canyon National Recreation Area Establishment of Sentinel Sampling Sites to Monitor Changes in Water and Sediment Quality and Biota Related to Visitor Use at Lake Powell, Arizona and Utah, 2004-2006

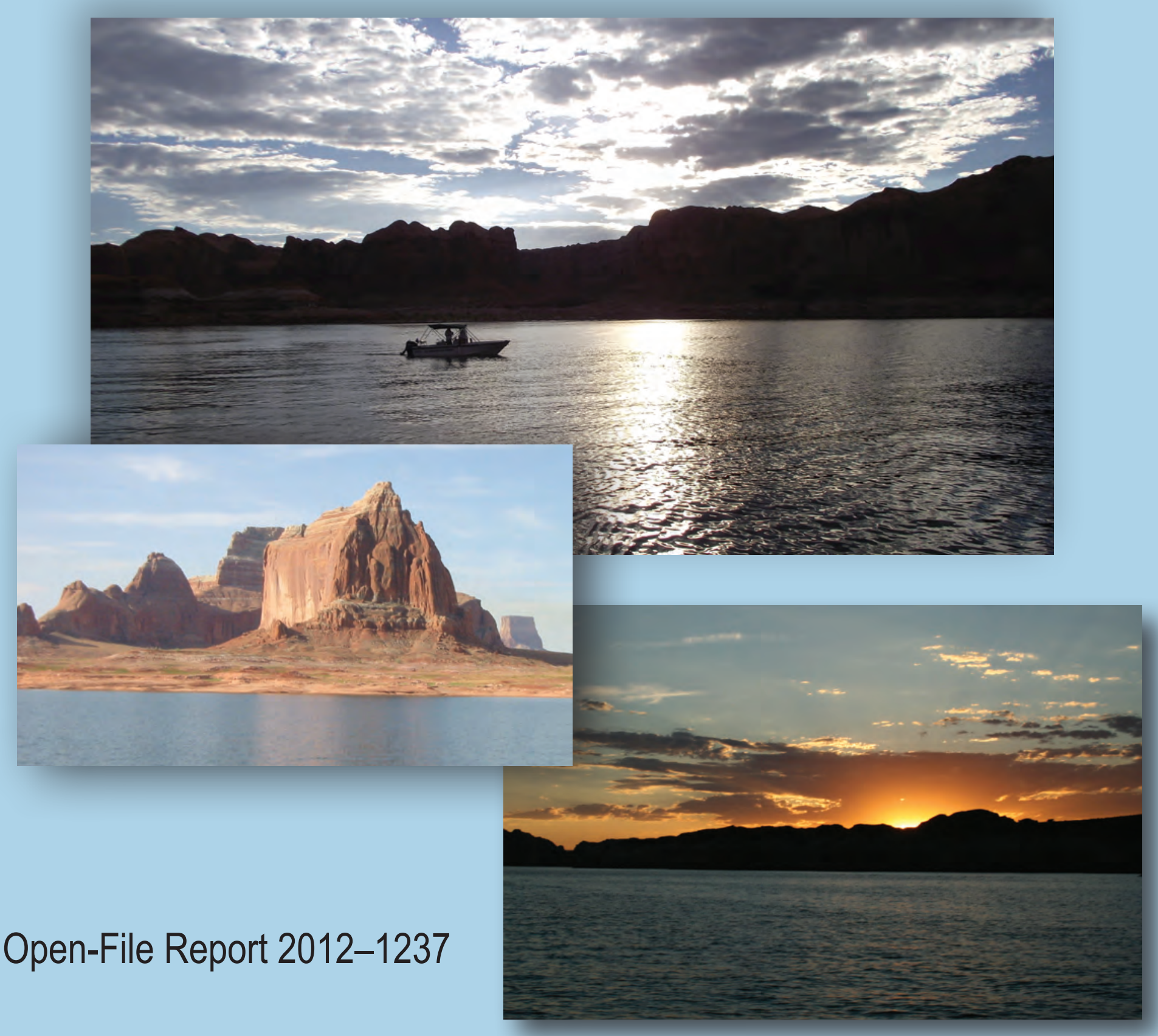

U.S. Department of the Interior U.S. Geological Survey 
Prepared in cooperation with the National Park Service, Glen Canyon National Recreation Area

\section{Establishment of Sentinel Sampling Sites to Monitor Changes in Water and Sediment Quality and Biota Related to Visitor Use at Lake Powell, Arizona and Utah, 2004-2006}

By Robert J. Hart, Howard E. Taylor, and G.M. Anderson

Open-File Report 2012-1237 


\section{U.S. Department of the Interior \\ KEN SALAZAR, Secretary \\ U.S. Geological Survey \\ Marcia K. McNutt, Director}

\section{U.S. Geological Survey, Reston, Virginia: 2012}

For an overview of USGS information products, including maps, imagery, and publications, visit http://www.usgs.gov/pubprod

For more information on the USGS - the Federal source for science about the Earth, its natural and living resources, natural hazards, and the environment, visit http://www.usgs.gov or call 1-888-ASK-USGS (1-888-275-8747).

To order this and other USGS information products, visit http://store.usgs.gov

Any use of trade, firm, or product names is for descriptive purposes only and does not imply endorsement by the U.S. Government.

Although this information product, for the most part, is in the public domain, it also may contain copyrighted materials as noted in the text. Permission to reproduce any copyrighted items must be secured from the copyright owner.

Suggested citation:

Hart, R.J., Taylor, H.E., and Anderson, G.M., 2012, Establishment of sentinel sampling sites to monitor changes in water and sediment quality and biota related to visitor use at Lake Powell, Arizona and Utah, 2004-2006: U.S. Geological Survey Open-File Report 2012-1237, 25 p. 


\section{Contents}

Abstract

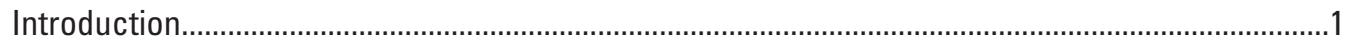

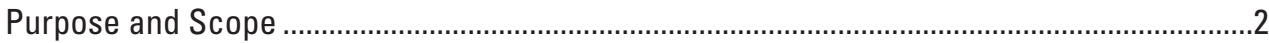

Lake Powell Characteristics and Visitor Use ..........................................................................2

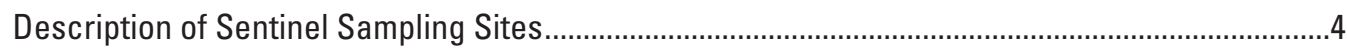

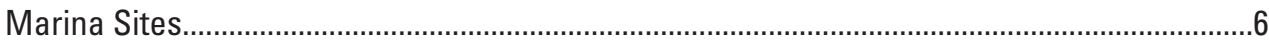

High-Use Side Canyons, Beaches, Bays, and Inflow Sites ....................................................

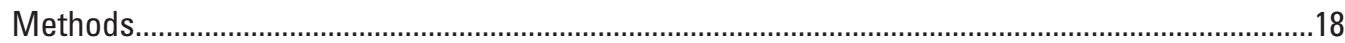

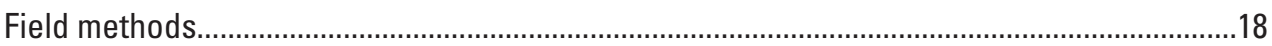

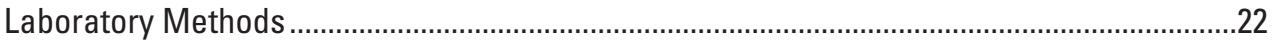

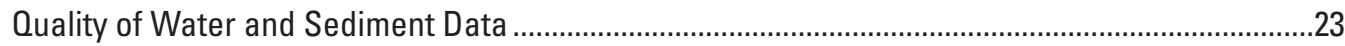

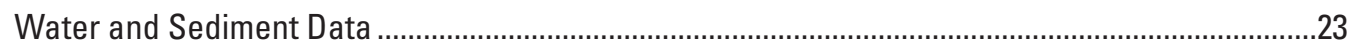

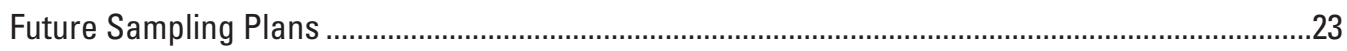

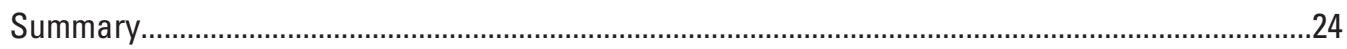

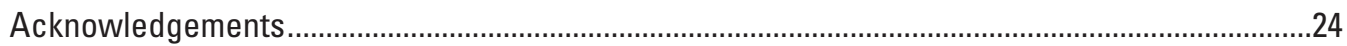

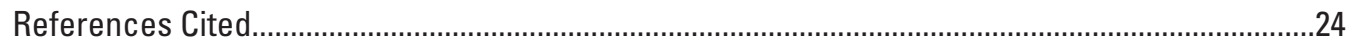

Appendixes A-F .......................................................provided as an online electronic supplement

A. Discrete measurements of depth, water temperature, specific conductance, $\mathrm{pH}$, and Secchi disk depth at sentinel sites, Lake Powell.

B. Bin averaged data of depth profile measurements of depth, water temperature, specific conductance, $\mathrm{pH}$, dissolved oxygen, and turbidity at sentinel sites, Lake Powell.

C. Dissolved concentrations of major ions, nutrients, and organic carbon at sentinel sites, Lake Powell.

D. Dissolved concentrations of trace elements and rare earth elements at sentinel sites, Lake Powell.

E. Dissolved concentrations of oil and grease, total petroleum hydrocarbons, and volatile organic compounds at sentinel sites, Lake Powell.

F. Total concentrations of polycyclic aromatic hydrocarbons in lakebed material at selected sentinel sites, Lake Powell.

\section{Figures}

1. Map Showing Locations of Sentinel Sampling Sites ................................................................

2. Graphs showing (a) reservoir elevation and (b) inflows to Lake Powell, 1990 to 2010 ..............4

3. Graphs showing the number of recreational visitors to Glen Canyon National Recreation Area from 1990-2010 .........................................................................................

4. Photographs of sampling areas. .................................................................................................

5. Photographs of (a) the SBE25, (b) NRP water sampler, (c) VOC sampler, and (d)

Ponar dredge sampler.

\section{Table}

1. Types of available data at the Sentinel sampling locations and data availability, $2001-2011$...........................provided as an online electronic supplement 


\section{Conversion Factors}

\begin{tabular}{|c|c|c|}
\hline Multiply & By & To obtain \\
\hline \multicolumn{3}{|c|}{ Length } \\
\hline centimeter $(\mathrm{cm})$ & 0.3937 & inch (in.) \\
\hline kilometer (km) & 0.6214 & mile (mi) \\
\hline $\operatorname{meter}(\mathrm{m})$ & 3.281 & foot $(\mathrm{ft})$ \\
\hline millimeter $(\mathrm{mm})$ & 0.03937 & inch (in.) \\
\hline \multicolumn{3}{|c|}{ Area } \\
\hline square hectometer $\left(\mathrm{hm}^{2}\right)$ & 2.471 & acre \\
\hline square kilometer $\left(\mathrm{km}^{2}\right)$ & 247.1 & acre \\
\hline \multicolumn{3}{|c|}{ Volume } \\
\hline cubic meter $\left(\mathrm{m}^{3}\right)$ & 0.0008107 & acre-foot (acre-ft) \\
\hline liter $(\mathrm{L})$ & 0.2642 & gallon (gal) \\
\hline \multicolumn{3}{|c|}{ Flow rate } \\
\hline meter per second $(\mathrm{m} / \mathrm{s})$ & 3.281 & foot per second $(\mathrm{ft} / \mathrm{s})$ \\
\hline \multicolumn{3}{|c|}{ Mass } \\
\hline $\operatorname{gram}(\mathrm{g})$ & 0.03527 & ounce, avoirdupois (oz) \\
\hline kilogram (kg) & 2.205 & pound avoirdupois (lb) \\
\hline
\end{tabular}

Temperature in degrees Celsius $\left({ }^{\circ} \mathrm{C}\right)$ may be converted to degrees Fahrenheit $\left({ }^{\circ} \mathrm{F}\right)$ as follows:

${ }^{\circ} \mathrm{F}=\left(1.8 \mathrm{x}^{\circ} \mathrm{C}\right)+32$.

Temperature in degrees Fahrenheit $\left({ }^{\circ} \mathrm{F}\right)$ may be converted to degrees Celsius $\left({ }^{\circ} \mathrm{C}\right)$ as follows:

${ }^{\circ} \mathrm{C}=\left({ }^{\circ} \mathrm{F}-32\right) / 1.8$.

\section{Abbreviated Water-Quality Units}

Chemical concentration and water temperature are given only in metric units. Chemical concentration in water is given in milligrams per liter $(\mathrm{mg} / \mathrm{L})$, micrograms per liter $(\mu \mathrm{g} / \mathrm{L})$, or nanograms per liter (ng/L). Milligrams per liter is a unit expressing the solute mass (milligrams) per unit volume (liter) of water. One thousand micrograms per liter is equivalent to 1 milligram per liter. For concentrations less than 7,000 milligrams per liter, the numerical value is about the same as for concentration in parts per million. Specific conductance is given in microSiemens per centimeter at 25 degrees Celsius $(\mu \mathrm{S} / \mathrm{cm})$. Chemical concentration in bottom sediment is given in grams per kilogram $(\mu \mathrm{g} / \mathrm{kg})$, micrograms per gram $(\mu \mathrm{g} / \mathrm{g})$, milligrams per kilogram $(\mathrm{mg} /$ $\mathrm{kg}$ ), or micrograms per kilogram $(\mu \mathrm{g} / \mathrm{kg})$. Grams per kilogram is equal to parts per thousands (ppt). Milligrams per kilogram and micrograms per gram are equal to parts per million (ppm). Micrograms per kilogram are equal to parts per billion (ppb).

\section{Datums}

Vertical coordinate information is referenced to the North American Vertical Datum of 1988 (NAVD 88)

Horizontal coordinate information is referenced to the North American Datum of 1983 (NAD 83)

Elevation, as used in this report, refers to the distance above the vertical datum 


\section{Acronyms and Symbols}

BTEX benzene, toluene, ethylbenzene, and xylene

DEET N,N-diethyl-meta-toluamide

EDTA ethylenediaminetetraacetic acid

GC/MS gas chromatography/mass spectrometry

GLCA Glen Canyon National Recreation Area

GPS Global Positioning System

ICP-AES inductively coupled plasma-atomic emission spectrometry

ICP-MS inductively coupled plasma-mass spectrometry

LDL laboratory detection limit

MCL maximum contaminant level

MPN most probable number

MTBE methyl-tertiary-butyl ether

NIST National Institute of Standards and Technology

NPEC nonylphenolpolyethoxycarboxylate

NRP National Research Program of the U.S. Geological Survey

NPS National Park Service

NTA nitrilotriacetic acid

NWQLU.S. Geological Survey National Water Quality Laboratory

PTFE polytetrafluroethane

PWC personal watercraft

REE rare earth element

TPH total petroleum hydrocarbon

USEPA U.S. Environmental Protection Agency

USGS U.S. Geological Survey

VOC volatile organic compound

$\begin{array}{llll}\text { Al } & \text { aluminum } & \mathrm{Na} & \text { sodium } \\ \mathrm{As} & \text { arsenic } & \mathrm{NH}_{4} & \text { ammonium } \\ \mathrm{B} & \text { boron } & \mathrm{Ni} & \text { nickel } \\ \mathrm{Ba} & \text { barium } & \mathrm{NO}_{2} & \text { nitrite } \\ \mathrm{Br} & \text { bromine } & \mathrm{NO}_{3} & \text { nitrate } \\ \mathrm{Ca} & \text { calcium } & \mathrm{Nd} & \text { neodymium } \\ \mathrm{Cd} & \text { cadmium } & \mathrm{P} & \text { phosphorus }\end{array}$




$\begin{array}{llll}\mathrm{Ce} & \text { cerium } & \mathrm{Pb} & \text { lead } \\ \mathrm{Cl} & \text { chloride } & \mathrm{PO}_{4} & \text { phosphate } \\ \mathrm{Co} & \text { cobalt } & \mathrm{Pr} & \text { praseodymium } \\ \mathrm{Cr} & \text { chromium } & \mathrm{Rb} & \text { rubidium } \\ \mathrm{Cs} & \text { cesium } & \mathrm{Re} & \text { rhenium } \\ \mathrm{Cu} & \text { copper } & \mathrm{S} & \text { sulfur } \\ \mathrm{Dy} & \text { dysprosium } & \mathrm{Sb} & \text { antimony } \\ \mathrm{Er} & \text { erbium } & \mathrm{Se} & \text { selenium } \\ \mathrm{Eu} & \text { europium } & \mathrm{SiO} & \text { silica } \\ \mathrm{Fe} & \text { iron } & \mathrm{SO} 4 & \text { sulfate } \\ \mathrm{Ga} & \text { gallium } & \mathrm{Sr} & \text { strontium } \\ \mathrm{Gd} & \text { gadolinium } & \mathrm{Sm} & \text { samarium } \\ \mathrm{HCl} & \text { hydrochloric acid } & \mathrm{Tb} & \text { terbium } \\ \mathrm{Hg} & \text { mercury } & \mathrm{Te} & \text { tellurium } \\ \mathrm{HNO}{ }_{3} & \text { nitric acid } & \mathrm{Th} & \text { thorium } \\ \mathrm{Ho} & \text { holmium } & \mathrm{Tl} & \text { thallium } \\ \mathrm{K} & \text { potassium } & \mathrm{Tm} & \text { thulium } \\ \mathrm{K} \mathrm{CrO}_{7} & \text { potassium dichromate } & \mathrm{U} & \text { uranium } \\ \mathrm{La} & \text { lanthanum } & \mathrm{V} & \text { vanadium } \\ \mathrm{Li} & \text { lithium } & \mathrm{W} & \text { tungsten } \\ \mathrm{Lu} & \text { lutetium } & \mathrm{Y} & \text { yttrium } \\ \mathrm{Mg} & \text { magnesium } & \mathrm{Yb} & \text { ytterbium } \\ \mathrm{Mn} & \text { manganese } & \mathrm{Zr} & \text { zirconium } \\ \mathrm{Mo} & \text { molybdenum } & & \\ & & & \end{array}$




\title{
Establishment of Sentinel Sampling Sites to Monitor Changes in Water and Sediment Quality and Biota Related to Visitor Use at Lake Powell, Arizona and Utah, 2004-2006
}

\author{
By Robert J. Hart', Howard E. Taylor', and G.M. Anderson ${ }^{2}$
}

\section{Abstract}

Twenty sentinel sampling sites were established and sampled during 2004-06 at Lake Powell, Arizona and Utah, by the U.S. Geological Survey and the National Park ServiceGlen Canyon National Recreation Area. The sentinel sampling sites provide sampling locations on Lake Powell, the Nation's second largest reservoir that can be visited and sampled repeatedly over time to monitor changes in water and sediment quality and also biota. The sites were established in response to an Environmental Impact Statement that addressed the use of personal watercraft on Lake Powell. The use of personal watercraft can potentially introduce hydrocarbons and other contaminants and are of concern to the health of visitors and aquatic habitats of these environments. Data from this initial sampling period (2004-06) include (1) discrete measurements of water temperature, specific conductance, $\mathrm{pH}$, and water clarity; (2) major ions, nutrients, and organic carbon; (3) trace elements including rare earths; (4) organic compounds including oil and grease, total petroleum hydrocarbons, and volatile organic compounds; (5) polycyclic aromatic hydrocarbons in lakebed sediments; and (6) continuous depth profile measurements of water temperature, specific conductance, $\mathrm{pH}$, dissolved oxygen, and turbidity. Also, the National Park Service-Glen Canyon National Recreation Area collected bacteria samples during this initial sampling period.

\section{Introduction}

The National Park Service (NPS) has become increasingly concerned by the use of personal watercraft (PWC) on the Nation's lakes and reservoirs that NPS manages and the contamination that the use of PWC potentially introduces into

${ }^{1}$ U.S. Geological Survey

${ }^{2}$ National Park Service the water. PWC that use two-stroke combustion engines burn gasoline inefficiently. As much as 30 percent of the gasoline is discharged unburned into the environment (California Environmental Protection Agency, 1999). Benzene, toluene, ethyl benzene, xylene (BTEX compounds), and methyl tertiary butyl ether (MTBE; a fuel oxygenate additive) are some constituents of gasoline that can be discharged to the waters. During 2003, the NPS adopted special regulations through the process of an Environmental Impact Statement (EIS) to manage the use of PWC on Lake Powell. After December 31, 2012, PWC that does not meet the 2006 emission standards set by Environmental Protection Agency (EPA) for the manufacturing of two-stroke combustion engines are not permitted to be operated on Lake Powell. The preferred alternative in the final EIS commits the Glen Canyon National Recreation Area (GLCA) to a monitoring program that requires the collection and analysis of baseline water and sediment- quality data (Federal Register, 2003).

During 2001-02, the U.S. Geological Survey (USGS) and the GLCA evaluated the effects of natural and human-induced contaminants on water and sediment chemistry and bacteria in the Knowles, Forgotten, and Moqui Canyons (Hart and others, 2004). Also, Hart and others (2005) completed an evaluation of contaminates in sediment deposits of the Colorado River inflow area to Lake Powell.

Results of that work provided the design for establishing sentinel sampling sites in 2004 throughout Lake Powell to begin documenting the presence of contaminants that are associated with visitor use. The USGS-Grand Canyon Monitoring and Research Center (GCMRC) has been monitoring mainstem Colorado River sites on Lake Powell since the mid-1960s (Vernieu, 2009). Unlike the sentinel sampling sites, which focus on chemical contaminants (organic and inorganic) introduced by human activity in high-use areas, the goal of the GCMRC monitoring program is to describe the physical, chemical, and biological conditions of the major strata of the reservoir in the main Colorado River channel and the primary tributary arms of the San Juan and Escalante Rivers. Both monitoring programs complement one another and provide the GLCA with necessary and pertinent information to better manage the recreational experience at Lake Powell. 


\section{Establishment of Sentinel Sampling Sites to Monitor Changes in Water and Sediment Quality at Lake Powell, Arizona and Utah}

The sentinel sites - sites used for long-term monitoring of water, sediment, and biota — were identified by the GLCA and the USGS and include marinas, high-use side canyons, beaches, bays, and tributary inflow areas, including the Colorado, San Juan, and the Escalante Rivers (fig. 1).

From 2004 to 2006, the USGS, in cooperation with GLCA, collected and analyzed water samples and lakebed material (sediment) from these sites. GLCA also collected water samples at the sites for bacteria determination. During 2004, samples were collected during the spring when visitation and use of petroleum-powered watercraft were relatively low. During 2005-06, samples were collected during the summer when visitation and the use of petroleum-powered watercraft were relatively high. These samples establish a baseline dataset for selected constituents in water and sediment for the sentinel sites.

\section{Purpose and Scope}

This report describes sentinel sampling sites established during 2004-06 and presents water and sediment chemical data collected during that time. Also, the GLCA collected bacteria samples at the sentinel sites. These initial sampling trips coincided with the low-visitation period (October-April) in 2004, and with the high-visitation period ( May-September) in 2005 and 2006. Discrete water measurements (measurements made at approximately $1 \mathrm{~m}$ below the water surface) were made and water samples were collected at each site and analyzed for major ions, nutrients, organic carbon, trace elements (including rare-earths), oil and grease, total petroleum hydrocarbons (TPHs), and volatile organic compounds (VOCs). Lakebed sediment was collected at selected sentinel sites and analyzed for PAHs. Depth-profile data of water temperature, specific conductance, $\mathrm{pH}$, dissolved oxygen, and turbidity also were collected at each site. This report includes the chemical analysis data and a description and photograph of each site. All data (discrete measurements, water and sediment chemistry, and bin-averaged depth-profile measurements) are included in appendixes A-F.

\section{Lake Powell Characteristics and Visitor Use}

Lake Powell is strongly influenced by the hydrologic regime of the Colorado River (Marzolf and others, 1998). The annual high-flow period into the lake generally is from April through July, resulting from snowmelt on the western slope of the Rocky Mountains. During this period, the salt content of the Colorado River begins to decrease (generally less than 500 $\mathrm{mg} / \mathrm{L}$ of total dissolved solids). As inflows begin to decrease in the late summer (late July), the river begins to carry high salt concentrations (increasing to more than $1,000 \mathrm{mg} / \mathrm{L}$ of total dissolved solids). The increase in salt concentration is caused by tributaries to the Colorado River that drain arid portions of the basin and because irrigation-return flow from agricultural land carries salts (Marzolf and others, 1998). The physical and chemical characteristics of Lake Powell respond to these changing hydrologic conditions, but also to other variables including solar radiation (heating), and atmospheric conditions (wind, cloud cover, and composition). The lake generally will stratify into distinct density layers, with the upper layer (the epilimnion) being mixed resulting mostly from thermal control of density. This layer is the lighted zone (euphotic) and defines the spatial extent of photosynthesis. For layers deeper than this mixed zone (the metalimnion and hypolimnion), light is limited and chemical and biological processes occur without the influence of the atmospheric exchange or oxygenproducing photosynthesis (Marzolf and others, 1998). It is important to document these processes when collecting water or biological samples in order to evaluate the vertical and longitudinal variations in the water chemistry.

During 2004-06, reservoir elevation (or levels) and inflows to Lake Powell reflected decreased runoff from snowmelt in the upper Colorado River Basin (fig. $2 A$ and $2 B$ ). Prior to 2004, from about 1995 to 2000 , lake elevations fluctuated annually, approaching full reservoir pool elevation of 3,700 ft during mid-summer of those years (fig. $2 A$ ). Since 1980 , the reservoir elevation was lowest during 2005 , when the lake reached an elevation of about 3,555 ft (fig. $2 A$ ) which is $145 \mathrm{ft}$ below the full reservoir conservation pool level of 3,700 ft. Reservoir levels have been steadily declining beginning in about 2000 . Two sampling trips were completed in 2004 during March 23-25 and April 13-14. The reservoir elevation in March and April 2004 was about 3,583 ft with slight fluctuations between those dates (fig. 2A). The 2004 sampling trip occurred during the early onset of snowmelt runoff to the lake.

The reservoir elevation continued to decline following the 2004 sampling trip in late March when it reached its record low at an elevation of about 3,555 ft. The lake began to fill the following March, and by the July 18-21, 2005 sampling trip, the lake elevation was $3,607 \mathrm{ft}$, which was about $24 \mathrm{ft}$ higher than the 2004 sampling trips and also the peak elevation for 2005. The 2005 sampling trip occurred near the tail end of the peak snowmelt runoff period.

From the July 2005 sampling trip to the last trip during July 9-14, 2006, the reservoir reached a level of about 3,609 $\mathrm{ft}$, which was marginally higher than the level recorded during the 2005 sampling trip. This sampling trip also occurred during the tail end of the peak snowmelt runoff period. Lake Powell's elevation generally increased with seasonal fluctuations since the 2006 sampling trip (fig. 2A).

Recreational visitation to GLCA, which includes Lake Powell, surrounding lands, and a 16-mile reach of the Colorado River downstream of the Glen Canyon Dam, averaged about 2,560,000 visitors per year during 1990-2010, and averaged about 1,879,000 visitors per year during 2004-06 (fig. 3; National Park Service, 2011). Recreational visitation includes multiple types of use of GLCA by visitors, such as campground use (tents and recreational vehicles), overnight stays, backcountry hiking, watercraft rental, and lodging in the Park. During 1990-2010, visitation was 


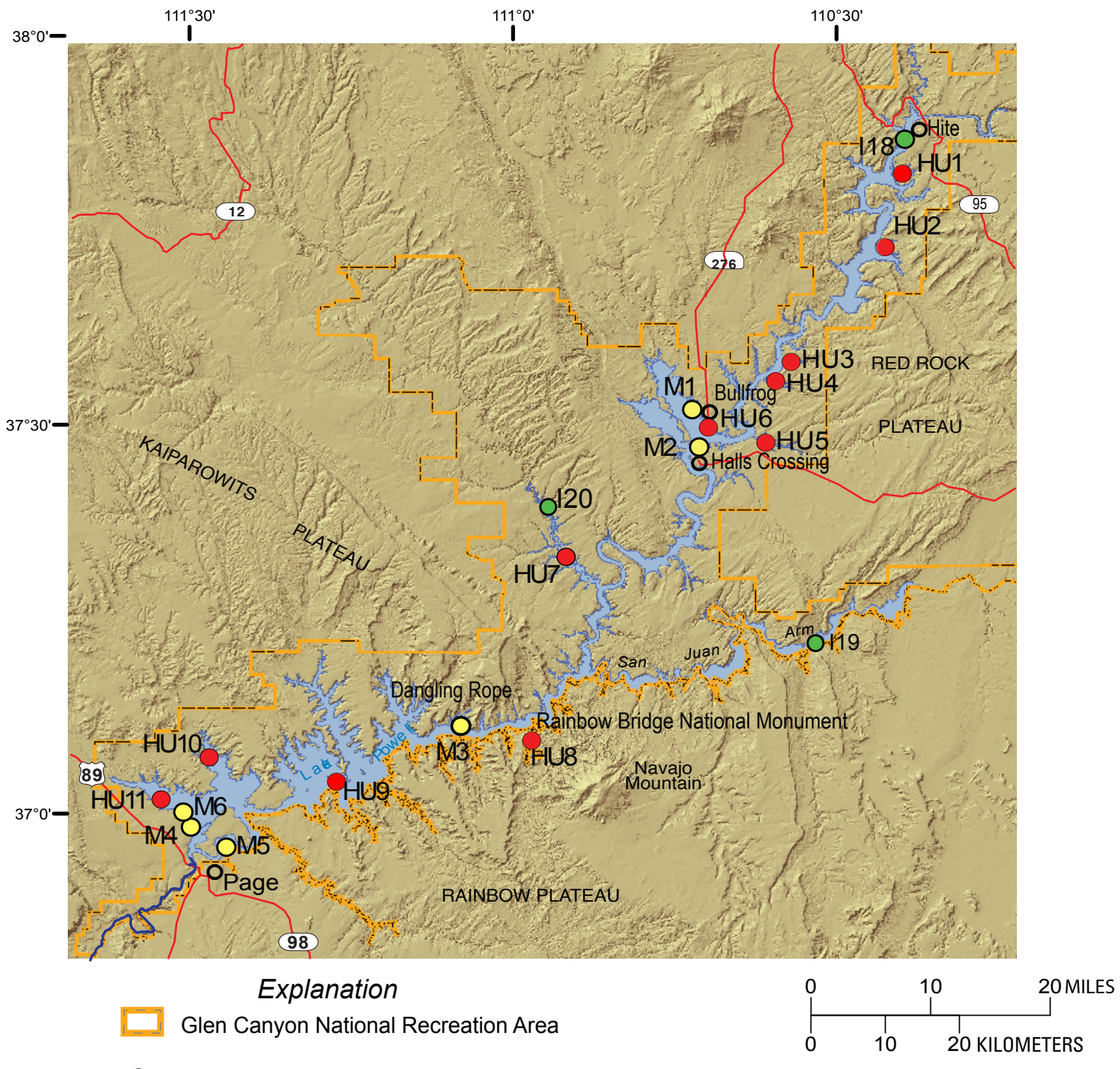

- Towns or communities

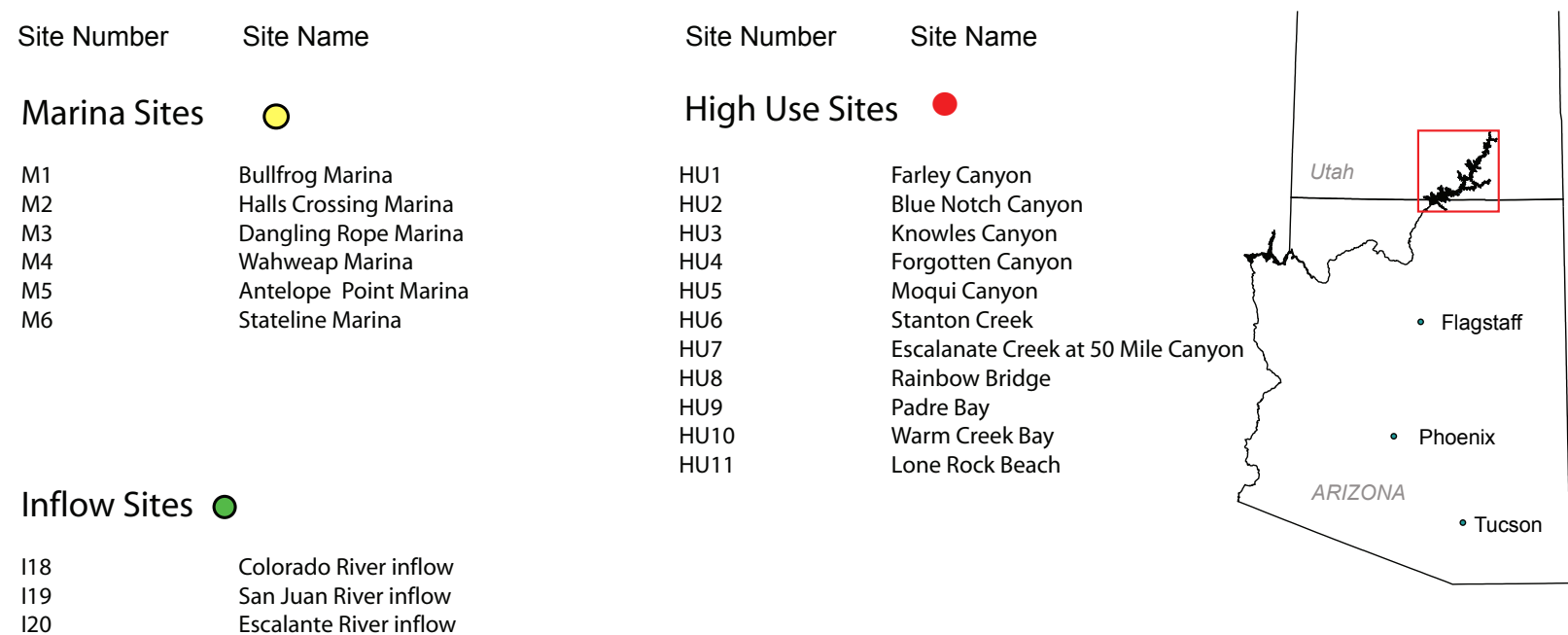

Figure 1. Map showing locations of sentinel sampling sites, Lake Powell, Arizona and Utah. 


\section{Establishment of Sentinel Sampling Sites to Monitor Changes in Water and Sediment Quality at Lake Powell, Arizona and Utah}

highest in 1992 with 3,587,754 visitors (fig. 3). During the establishment of the sentinel sites in 1990-2010, visitation was lowest in 2004 with 1,841,845 visitors (fig. 3). Factors affecting recreational visitation may include but are not limited to, economic considerations, such as costs associated with recreation, reservoir conditions such as low lake levels, or general perceptions the public might have about Lake Powell conditions. Since 2006 however, recreational visitation has consistently increased.

\section{Description of Sentinel Sampling Sites}

Twenty sentinel sampling sites were selected by the GLCA and the USGS as long-term monitoring sites for evaluating the effects of visitor use on water, sediment, and biological quality. The 20 sites were selected based on a several factors.
If a site was known to be frequented by visitors (high-visitor use) for boating, fishing, swimming, or other recreational opportunities, those sites were considered in the selection process. Other factors considered in selecting a site included (1) recreational carrying capacity (which considers the number of people, boats, and other activities that may impact the values the GLCA is offering or protecting in the National Recreation Area), (2) distance between canyons, (3) drainage area, and (4) watershed characteristics. Besides including high-visitor-use areas (side canyons, marinas, beach areas, and bays), three tributary inflow areas were included in the monitoring network.

Because Lake Powell is not a true lake, but rather a river that is dammed forming a reservoir (which is called Lake Powell), distances and locations of the sentinel sites are referenced to hydrologic terms. Distance between sites is described as being "upstream" or "downstream" and locations
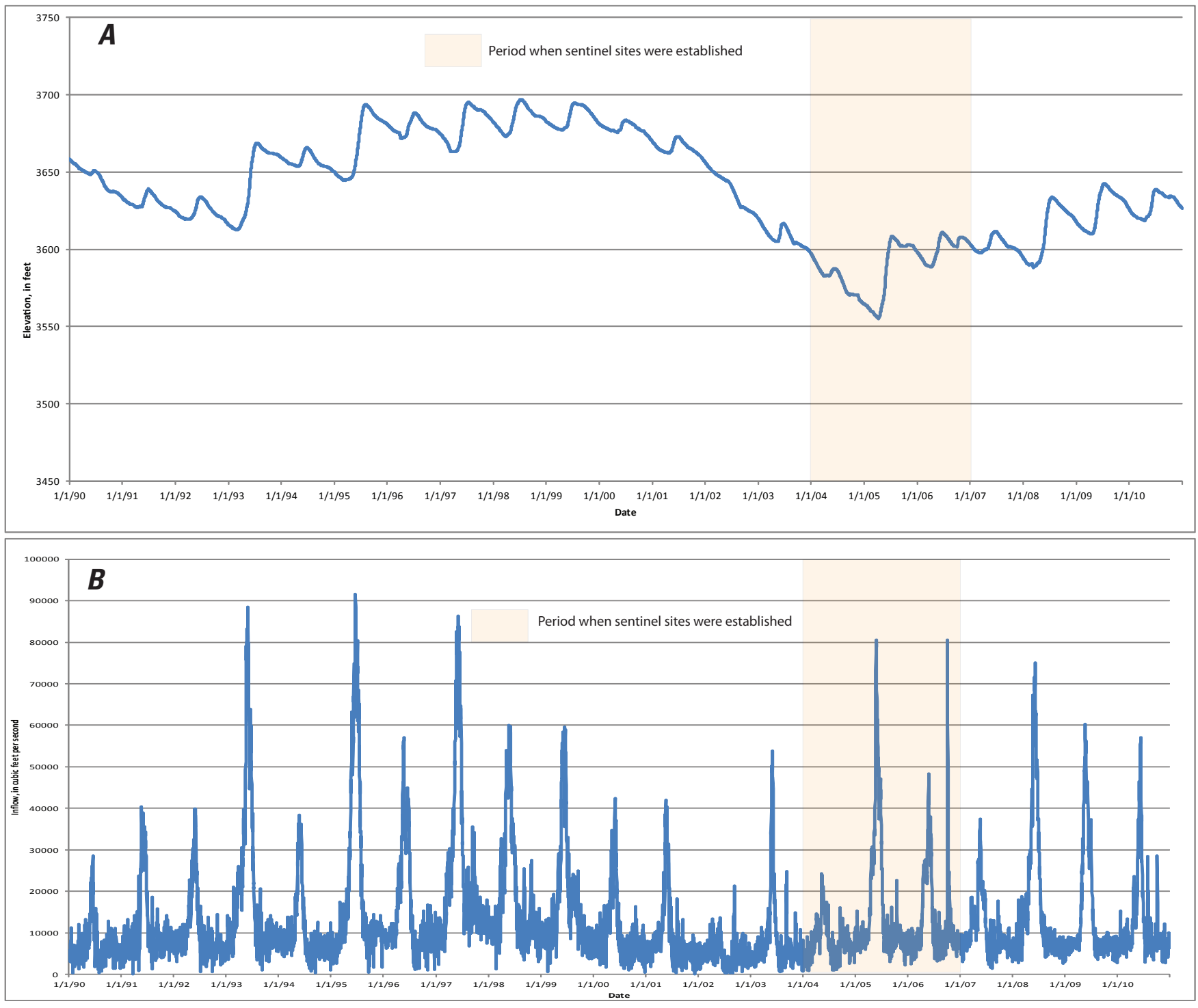

Figure 2. Graphs showing $(A)$ reservoir elevation and $(B)$ inflows to Lake Powell, Arizona and Utah, 1990-2010. 


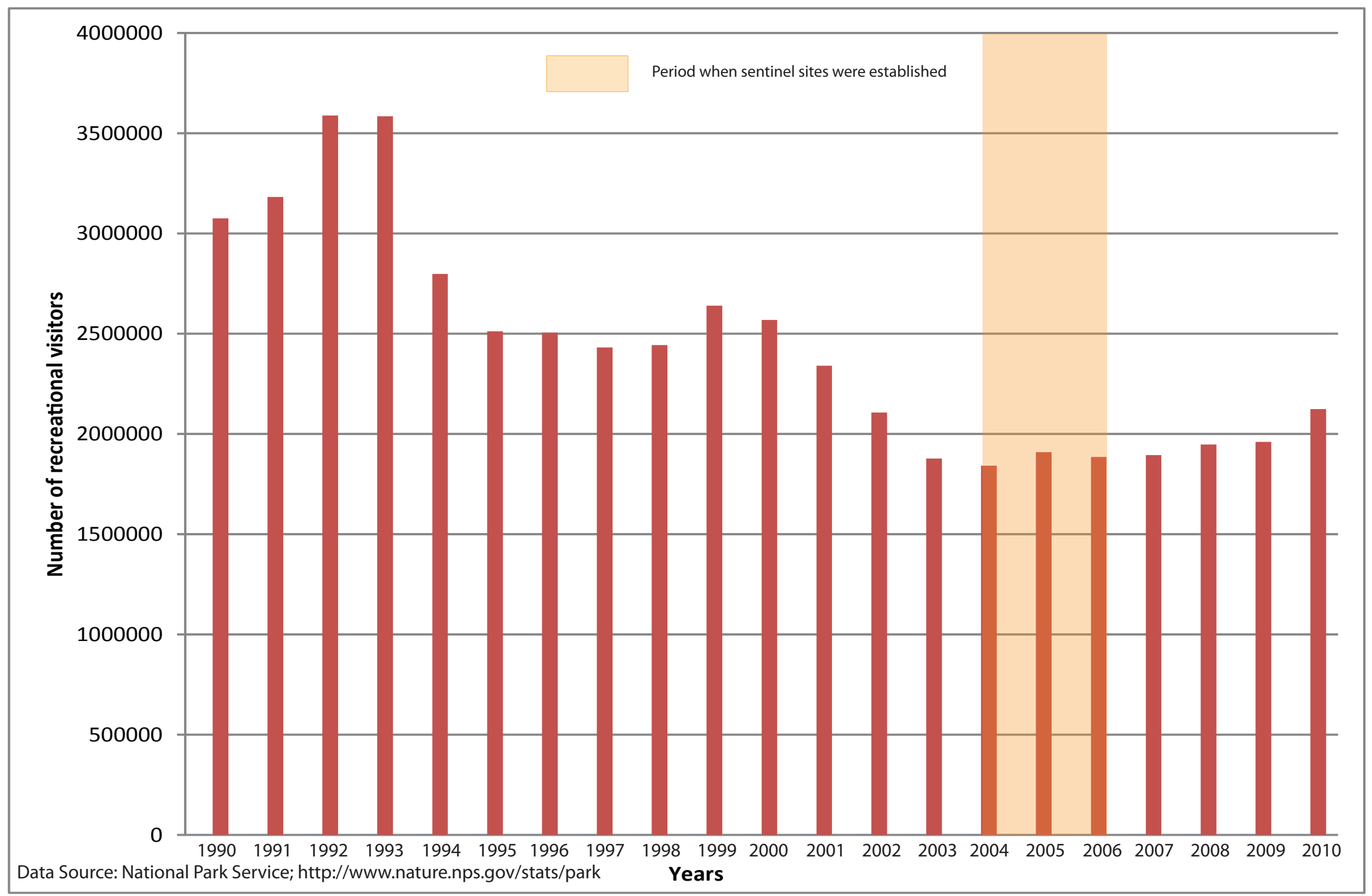

Figure 3. Graphs showing number of recreational visitors to Glen Canyon National Recreation Area, Lake Powell, Arizona and Utah," $1990-2010$. 
are referenced as being on "river right" or "river left" as the river flows downstream. Navigation buoys (mile markers) are deployed by GLCA beginning at Glen Canyon Dam (mile 0 ), following the original Colorado River channel upstream about $139 \mathrm{mi}$ to Hite, Utah. These buoys are deployed every $1 \mathrm{mi}$ to mark the river-channel distance and the deepest edges of the original channel. These buoys also are used to mark the original Wahweap Creek channel. The sentinel sites are referenced to the location of the navigation buoys. All sentinel sampling sites were geospatially referenced to latitude and longitude using a global positioning system (GPS); this information was used to develop the site information in the database (Schonauer, 2011).

\section{Marina Sites}

There are six marinas located on Lake Powell beginning at Bullfrog, Utah, downstream to to Wahweap, Arizona (fig. 1). Hite, Utah, at one time provided marina services at the far northeastern end of the lake (lake mile 139) but the marina was closed in 2003 due to declining reservoir levelshowever, other services, such as launch ramps, are still available. Marina sites are labeled with the letter "M" denoting a marina site, followed by a number sequentially increasing from upstream to downstream sites.

Site M1 Bullfrog Marina (site ID 373057110442300). This site was selected for the monitoring network because of the high potential for the introduction of contaminants from human activity related to marina services and from vehicular traffic. Houseboats are moored at the marina and the marina serves as the departure point for houseboat vacationers for this part of the lake. Bullfrog Marina is located approximately at mile marker 96 upstream on river right of Lake Powell (fig. 1). The sampling site is about $300 \mathrm{ft}$ from the fuel docks in the no-wake zone of the marina (fig. 4A). Bullfrog Marina provides full service to boaters and recreationists, providing launching services for houseboats, pump-out services, launch ramps, fuel docks, convenience marina stores, and full service boat repair and maintenance. A unique service in this area of the lake is the ferry service (the Charles Hall Ferry) that provides transportation between Bullfrog and Halls Crossing. The ferry operates on a daily basis during the summer but not during the winter (Aramark Parks and Destinations, 2010). The ferry is capable of hauling most types of vehicles and 150 passengers.

\section{Site M2 Halls Crossing Marina (site ID}

372809110431200). - This site was selected for the monitoring network because of the high potential for the introduction of contaminants from human activity related to marina services and from vehicular traffic. Houseboats are moored at the marina and the marina serves as the departure point for houseboat vacationers for this part of the lake. Halls Crossing Marina is directly across the lake from Bullfrog
Marina at about mile marker 94 on river left (fig. 1). The sampling site is within the no-wake zone about $300 \mathrm{ft}$ from the fuel docks (fig. 4B). Like Bullfrog Marina, Halls Crossing Marina provides launching services for houseboats, launch ramps, fuel docks, full service repair and maintenance, and pump-out services.

\section{Site M3 Dangling Rope Marina (site ID}

370708111045100). - This site was selected for the monitoring network because of the high potential for the introduction of contaminants from human activity primarily related to marina services. Dangling Rope Marina is located near mile marker 43 on river right (fig. 1). The sampling site is within the no-wake zone about $150 \mathrm{ft}$ east of the fuel docks (fig. 4C). The marina is only accessible by water due to its isolated location. It provides limited services including fuel, pump-out services, minor boat repair, and a supply store where the popular Lake Powell root beer floats can be purchased. It is the only marina between Wahweap and Antelope Marinas in the lower part of the lake and Bullfrog and Halls Crossing Marinas (at mile markers 96 and 94, respectively).

\section{Site M4 Wahweap Marina (site ID 365933111285200).-}

Wahweap Marina is in the southeastern part of Lake Powell in Wahweap Bay, Arizona (fig. 1) about 4.5 mi upstream of Glen Canyon Dam. This is a high-use boat and traffic area because it is located at the primary entrance to Lake Powell near Page, Arizona. As with Bullfrog and Halls Crossing Marinas, houseboats are moored at the marina and the marina serves as the departure point for houseboat vacationers for primarily the lower part of the lake. The sampling location is about $300 \mathrm{ft}$ east of the fuel docks (fig. 4D). The marina provides a variety of services including lodging, gift stores, food services, full marina services including slips, boat rentals, dry storage, and fuel. The city of Page, Arizona is about $9 \mathrm{mi}$ from the marina.

\section{Site M5 Antelope Point Marina (site ID}

365759111254700). - Antelope Point Marina is the newest marina, located on the Navajo Nation on the southern end of Lake Powell on the original Colorado River channel upstream of Glen Canyon Dam (fig. 1). The marina became a full service marina in 2005 (it was not in service in 2004) and is operated by the Navajo Nation. The marina provides launching and mooring services for houseboats, fuel, supply store, and the "World's Largest Floating Restaurant" (Antelope Point, 2011). The sampling site is about $300 \mathrm{ft}$ from the fuel docks (fig. $4 E$ ). Because of the narrowness of the lake in this area, boat traffic can be congested during high-visitor use periods. Like Wahweap Marina, Antelope Point Marina is near Page, Arizona.

Site M6 Stateline Marina (site ID 370031111300100).Lake Powell at Stateline Marina, also referred to as Stateline Launch Ramp, is located in Waheap Bay about 6 mi upstream of Glen Canyon Dam (fig. 1) between Wahweap Marina (site M4) and Lone Rock Beach (site HU11). Houseboats are 
moored at the marina and the marina serves as the departure point for houseboat vacationers for primarily the lower part of the lake. It is a busy marina during the summer due to its proximity to Lone Rock Beach, Wahweap Marina, and the city of Page, Arizona. It also provides some services including fuel and boat rental. The sampling site is located at the floating docks (fig. 4F).

\section{High-Use Side Canyons, Beaches, Bays, and Inflow Sites}

There are 14 sites that are classified as high-use sites including (1) side canyons, (2) beaches, and (3) bays. Sampling sites at major tributary inflows also were established. The location of these sites begins at Farley Canyon at mile marker 133 and continues downstream to Lonerock Beach, which is about $9 \mathrm{mi}$ upstream of Glen Canyon Dam (fig. 1). These high-use sites are labeled with the letters "HU," followed by a number and sequentially increasing from upstream to downstream sites. The major inflow sites are labeled as "I" followed by a number.

Site HU1 Farley Canyon (site ID 374902110245200).Farley Canyon is a fairly exposed canyon with a gentle sloping shoreline. It is located near mile marker 133 on river left (fig. 1) and because it is a popular fishing location, it was included in the monitoring network. An access road from State Highway 93 to the shoreline of Farley Canyon provides primitive camping and "launch at your own risk" watercraft access, which is another source of potential contaminants to Lake Powell. The sampling site is near the far end of this small canyon (fig. 4G). The site also can be accessed from Hite launch ramps and Bullfrog and Halls Crossing launch ramps.

\section{Site HU2 Blue Notch Canyon (site ID 374322110264600).-Blue Notch Canyon also is a fairly exposed canyon with a gentle sloping shoreline. It is located near mile marker 123 on river left and like Farley Canyon, it was included in the monitoring network because it is a popular fishing location. An access road to the shoreline of Blue Notch Canyon provides primitive camping and "launch at your own risk" watercraft access, which is another source of potential contaminants to Lake Powell. The site also can be accessed from Hite launch ramps, as well as Bullfrog and Halls Crossing launch ramps. The location of Blue Notch is recognizable from the main lake by the promontory of Castle Butte on river left (fig. 4H). The sampling location is to the east of Castle Butte in Blue Notch Canyon.}

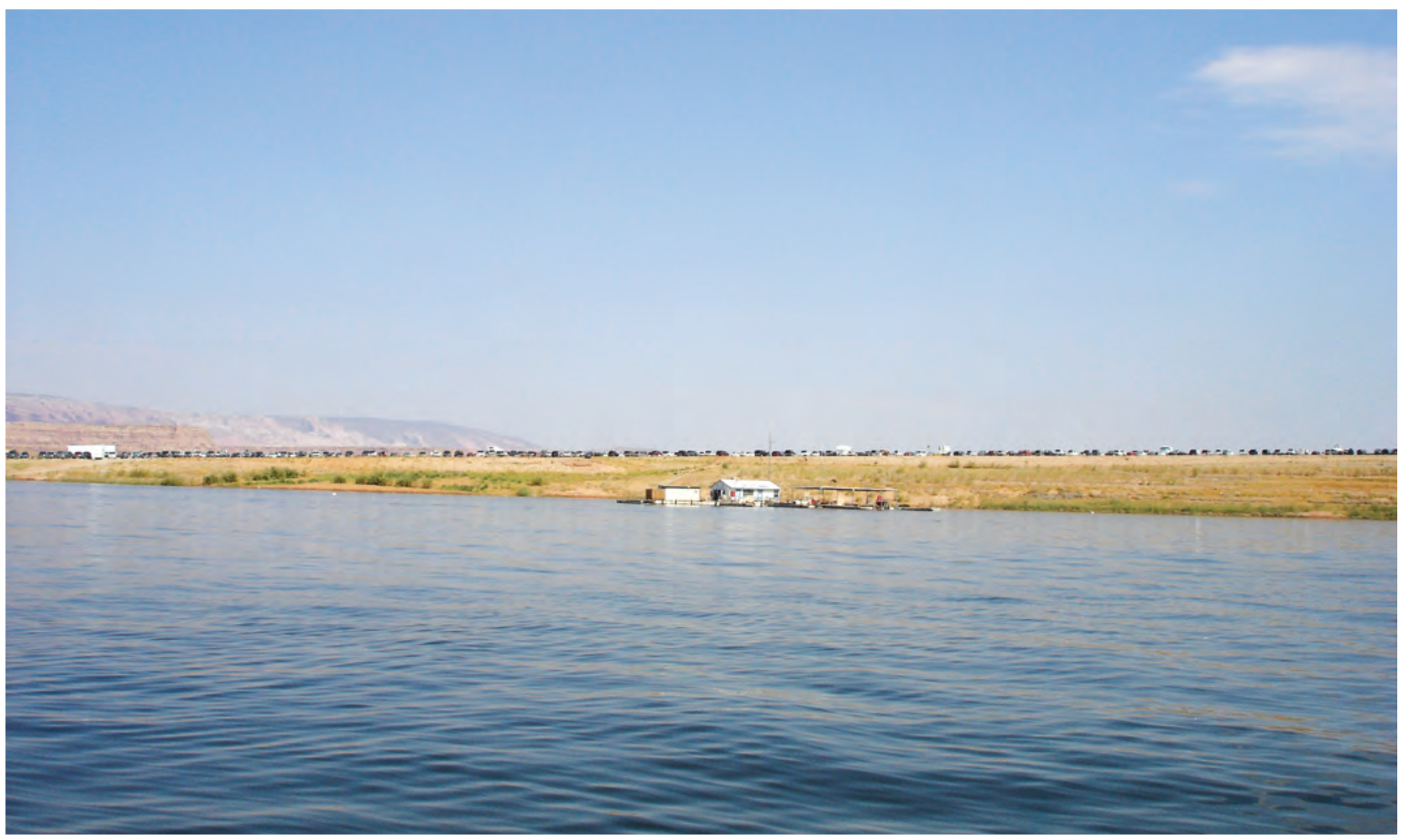

Figure 4A. Photograph of site M1 Bullfrog Marina (site ID 373057110442300) near sampling area. The sampling area is near the marina fuel docks to the left of the photo and is out of view. View is to the north. Summer 2005. 


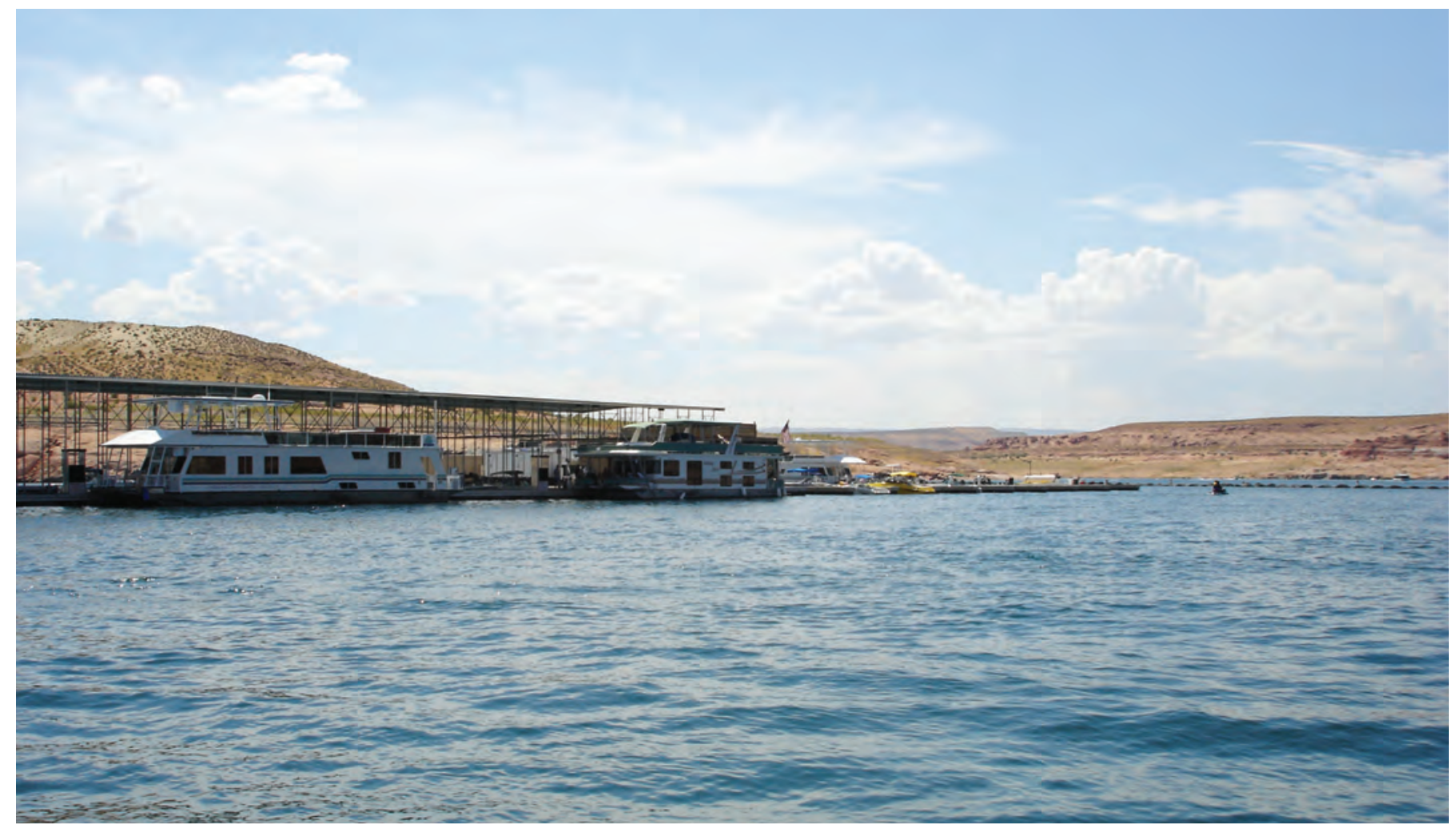

Figure 4B. Photograph of site M2 Halls Crossing Marina (site ID 372809110431200). View is to the south. Summer 2005.

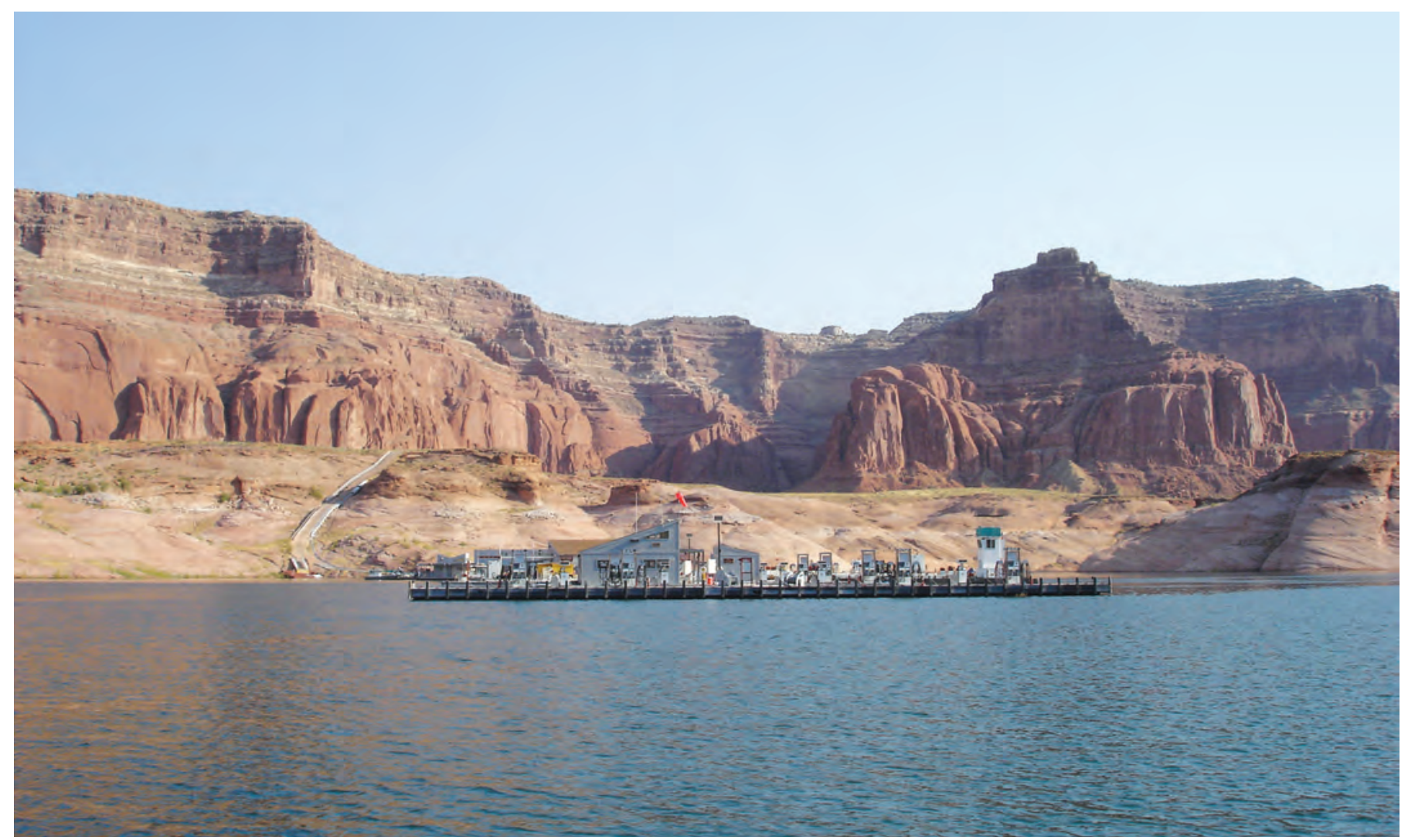

Figure 4C. Photograph of site M3 Dangling Rope Marina (site ID 370708111045100) sampling area. View is to the northeast. Spring 2004. 


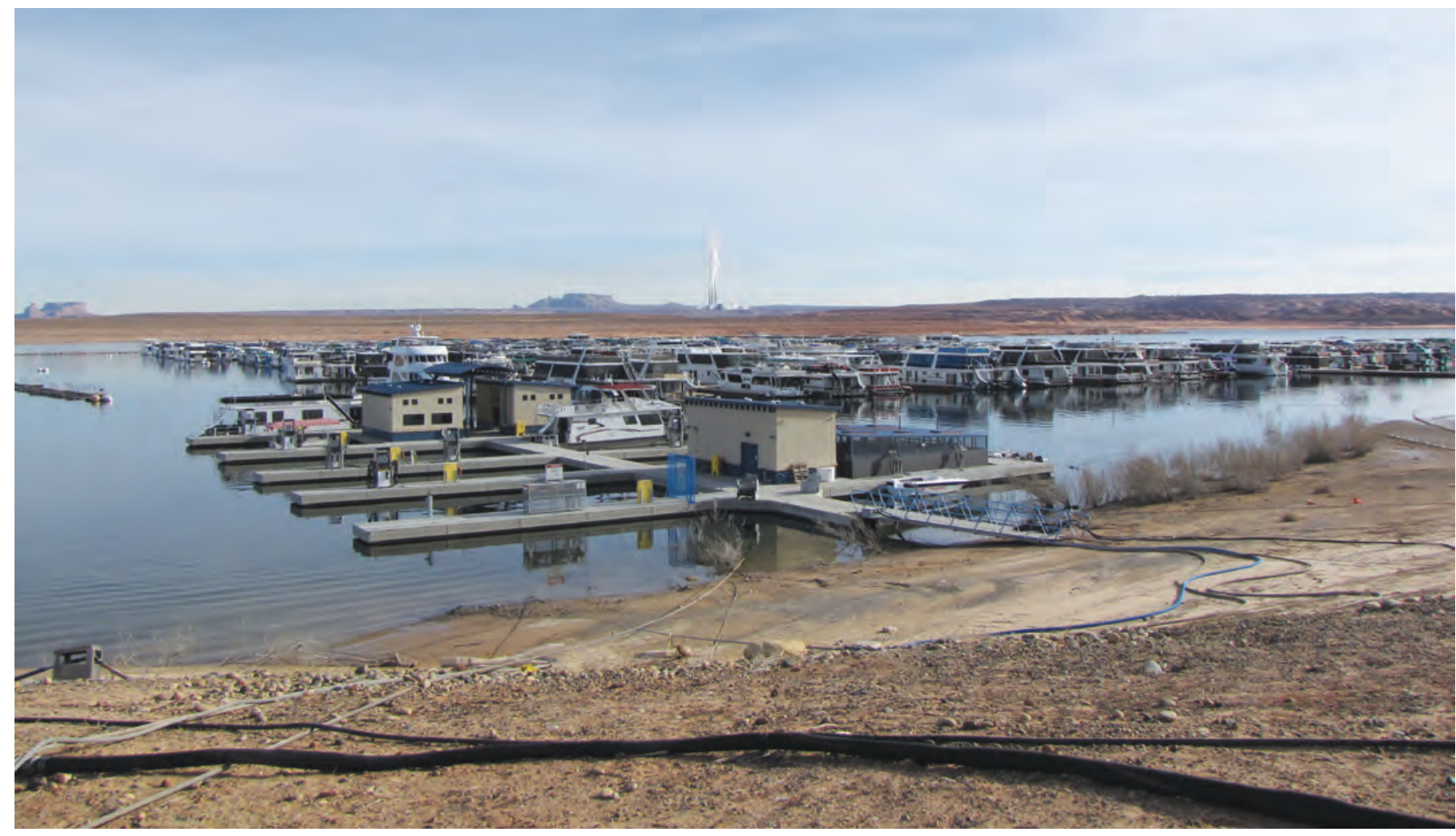

Figure 4D. Photograph of site M4 Wahweap Marina (site ID 365933111285200) sampling area. View is looking to the east. Winter 2012.

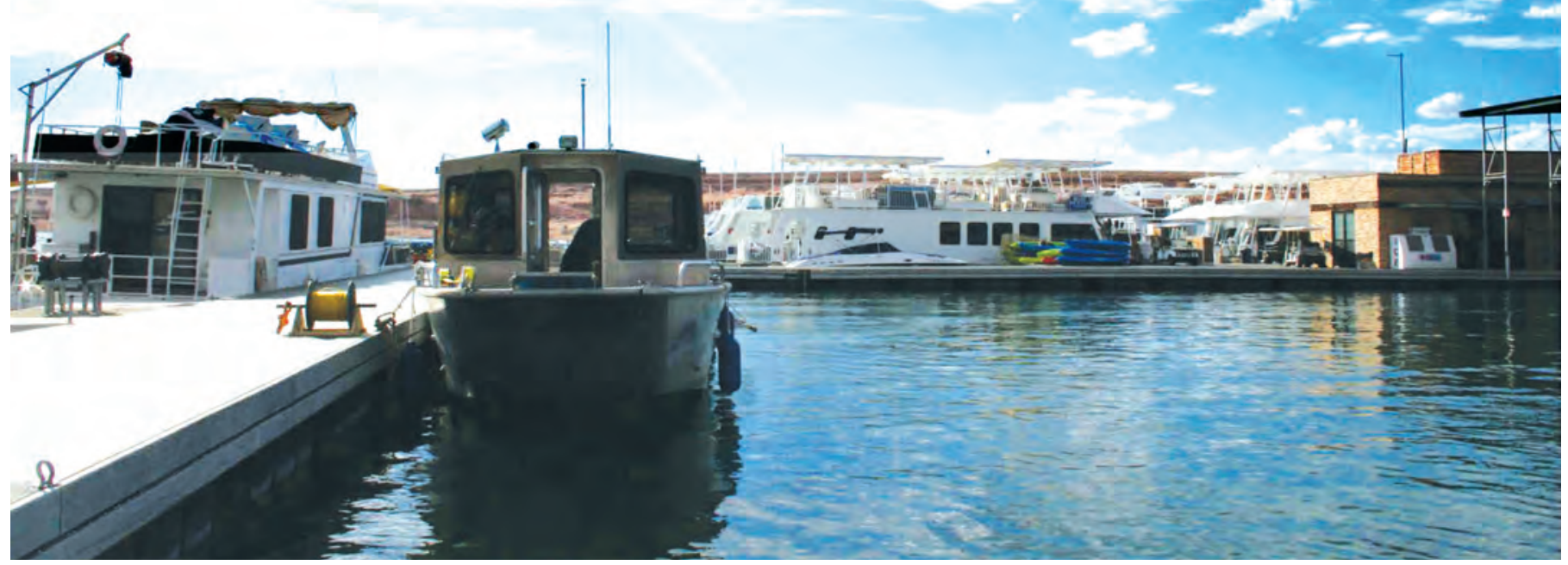

Figure 4E. Photograph of site M5 Antelope Point Marina (site ID 365759111254700) sampling area. View is to the southwest. Spring 2004. 


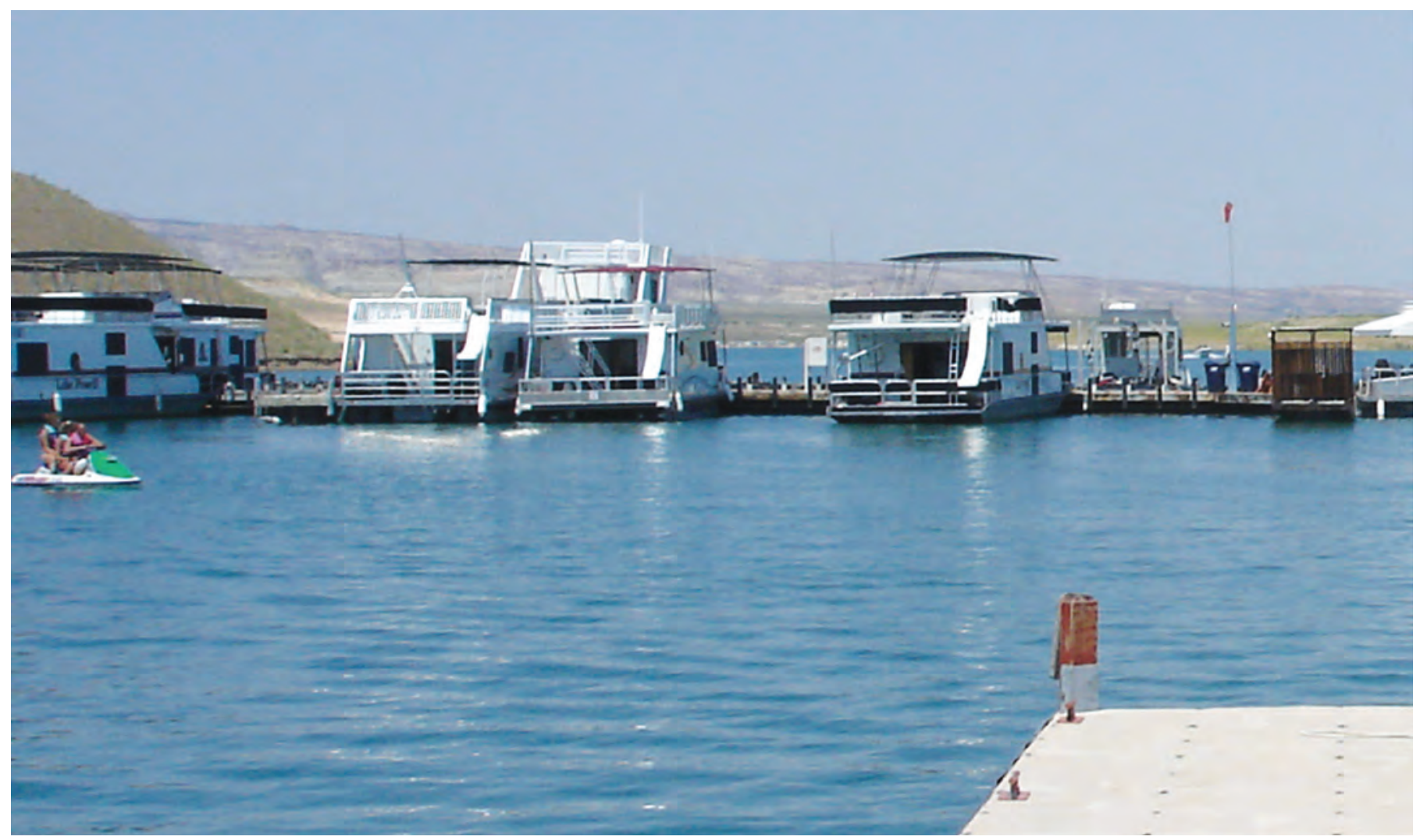

Figure 4F. Photograph of site M6 Lake Powell at State Line (site ID 370031111300100) sampling area. View is to the west. Summer 2011.

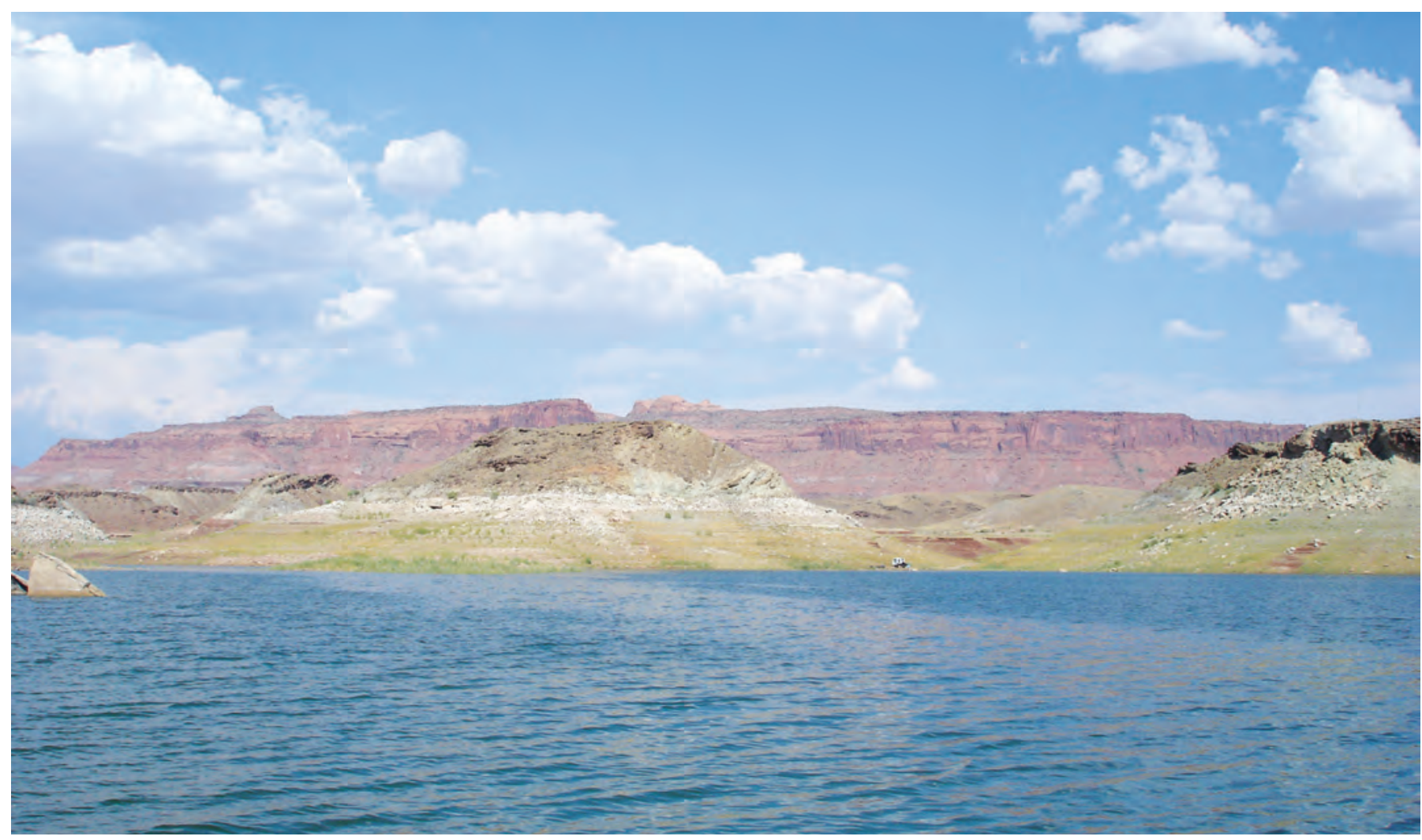

Figure 4G. Photograph of site HU1 Farley Canyon (site ID 374902110245200). View is looking upstream to the northeast. Summer 2005. 
Site HU3 Knowles Canyon (site ID 373438110350900 ). Knowles Canyon is located near mile marker 108 on river left, and it is a popular fishing site on Lake Powell. It also is popular for houseboat camping. Beaches are few for camping and their presence is a function of the reservoir elevation. Knowles Canyon is about 10 river miles upstream of Bullfrog Bay and is only accessible by watercraft. The canyon is characterized by steep, vertical canyon walls. This small canyon was intensively sampled during 2001-02 for organic and inorganic constituents (Hart and others, 2004). The sampling location is about $0.5 \mathrm{mi}$ upstream of the mouth of the canyon (fig. 4I).

Site HU4 Forgotten Canyon (site ID 373306110363700).Forgotten Canyon is located near mile marker 106 on river left, and is a popular fishing canyon and recreational boating area on Lake Powell. The canyon is larger than Knowles Canyon and it is a narrow and relatively confined canyon due to the steep, vertical canyon walls. There are several sandy beaches in the canyon that can accommodate several houseboat camps. A GLCA floating toilet is near the mouth of the canyon and the Defiance House archeological site is upstream of the mouth of the canyon. This canyon was intensively sampled during 2001-02 for organic and inorganic constituents (Hart and others, 2004). It is located about 8 river miles upstream from Bullfrog Bay and is only accessible by watercraft. The sampling location is about $1 \mathrm{mi}$ upstream of the mouth of the canyon (fig. $4 J$ ).

\section{Site HU5 Moqui Canyon (site ID 372838110372000).-}

Moqui Canyon is located near mile marker 100 on river left, about 4 river miles upstream of Bullfrog Bay. Moqui Canyon is a popular side canyon for all types of water recreation and consists of several camping beaches suitable for houseboats. At the full pool level of Lake Powell (3,700 ft), Moqui Canyon arm of Lake Powell extends miles from its mouth with Lake Powell and consists of several tributaries. The canyon and its tributaries are steep walled and quite narrow. This canyon was intensively sampled during 2001-02 for organic and inorganic constituents (Hart and others, 2004). The sampling site is about 2 mi upstream in Moqui Canyon (fig. $4 K$ ).

\section{Site HU6 Stanton Creek (site ID 372940110421600).-}

Stanton Creek flows into Bullfrog Bay at about mile marker 96 just southeast of Bullfrog Marina (site M1, fig. 1). Stanton Creek is a small tributary to Lake Powell but the area is popular for recreationists because it is easily accessed by boat or vehicle. Primitive camping exists on the shorelines and restroom facilities are provided by GLCA. It is an exposed tributary with a gentle sloping shoreline. The sampling site is

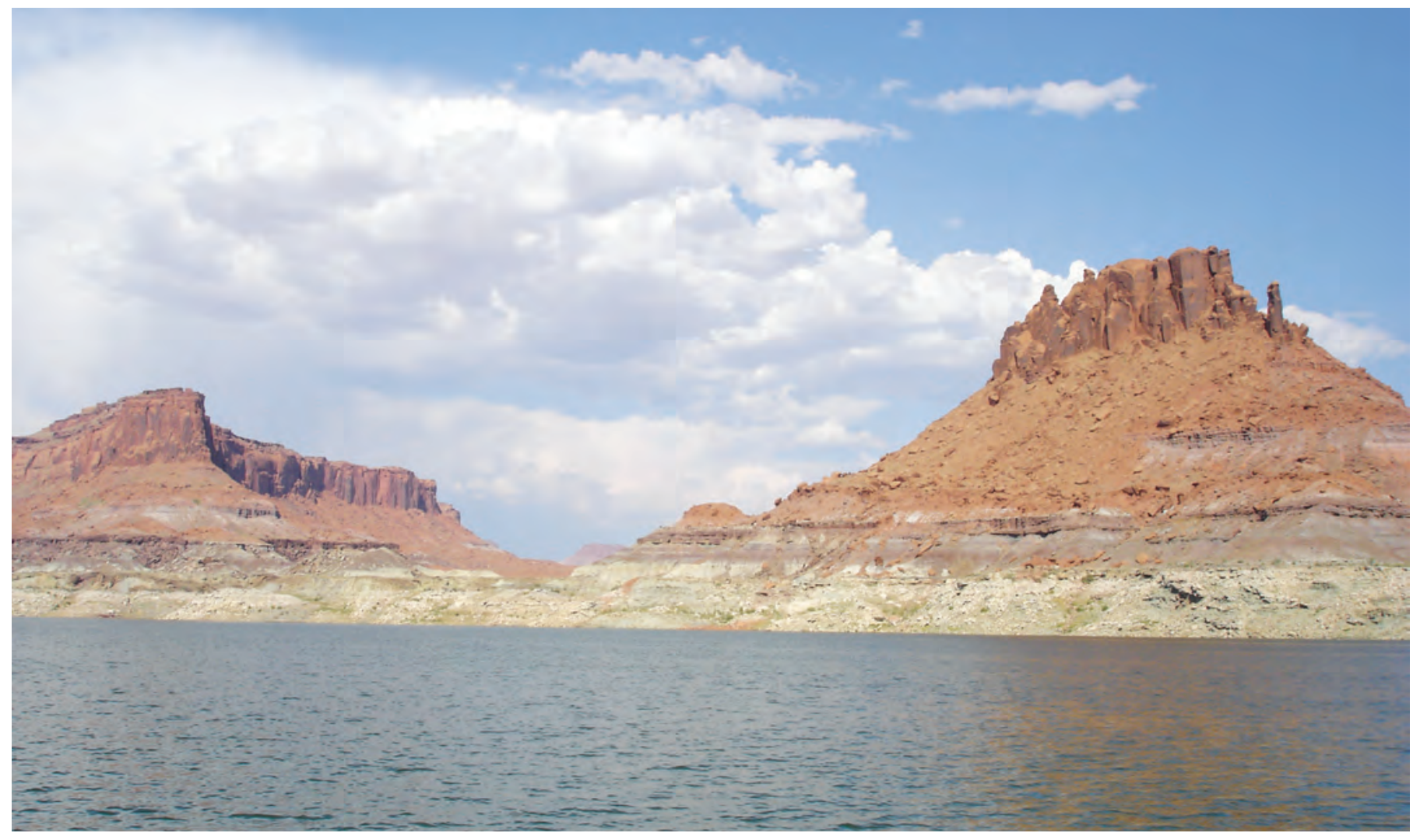

Figure 4H. Photograph of site HU2 Blue Notch Canyon (site ID 3743221102646i00). View is to the west. Summer 2005. 


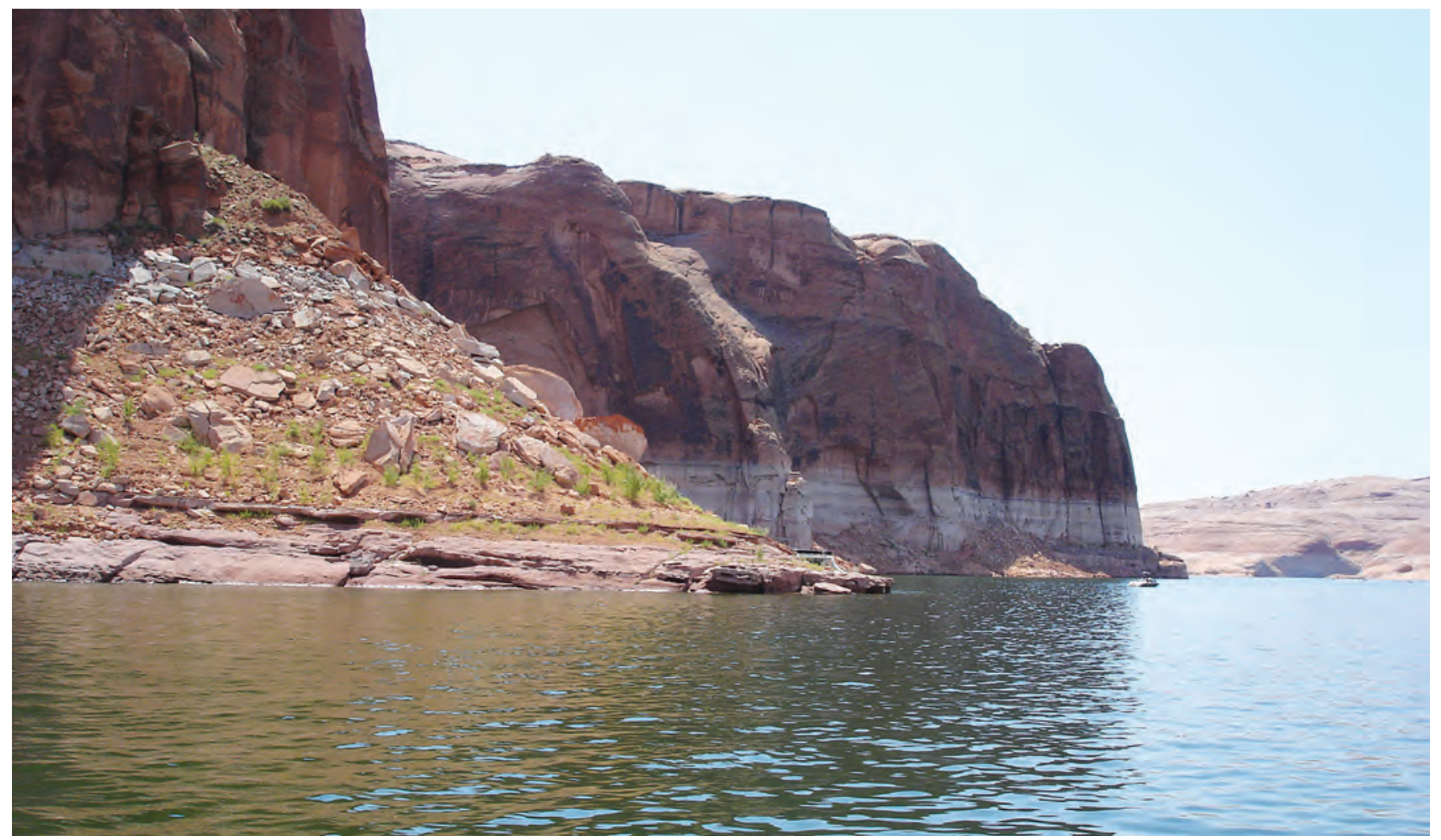

Figure 4I. Photograph of site HU3 Knowles Canyon (site ID 373438110350900). View is to the southwest. Summer 2004.

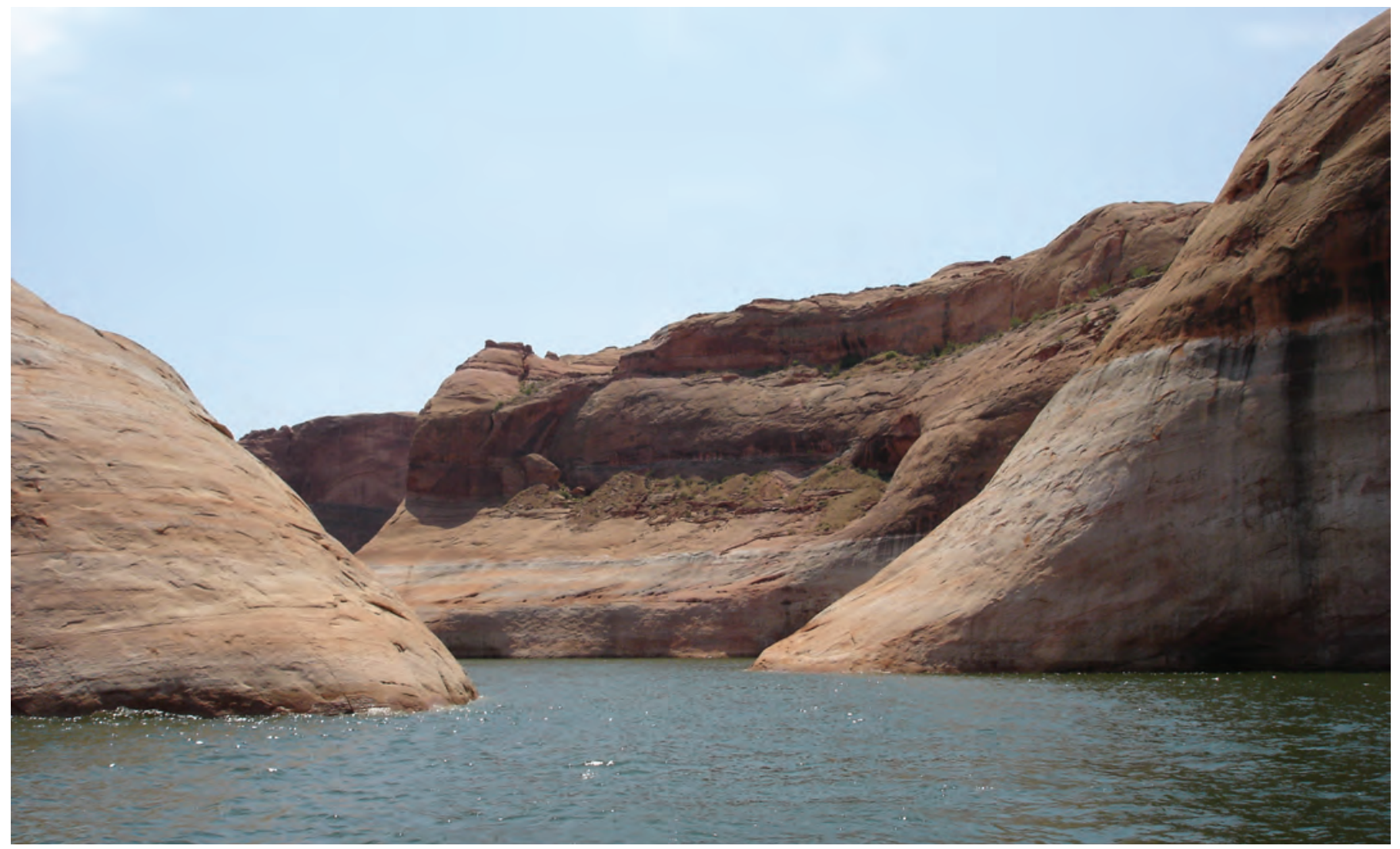

Figure 4J. Photograph of site HU4 Forgotten Canyon (site ID 373306110363700). View is looking upstream to the east. Summer 2005. 
several hundred feet upstream of the mouth of Stanton Creek to Lake Powell (fig. $4 L$ ).

\section{Site HU7 Escalante River below 50-Mile Canyon (site} ID 371938110553700 ). - This site is located about $9.3 \mathrm{mi}$ upstream of the mouth of the Escalante River and its inflow area (fig. 1). The sampling location is in the main channel of the Escalante River just downstream of the mouth of 50-Mile Canyon (a tributary to the Escalante River, fig. 4M). Boat traffic in this section of the Escalante River can be extremely congested at certain times of the high visitor-use season. No beaches are available at this site for camping.

\section{Site HU8 Rainbow Bridge National Monument (site ID} 370506110581600).-Rainbow Bridge National Monument is located in Forbidding Canyon on Bridge Creek (fig. 1) and is home to the world's largest known natural bridge. The site is in an extreme narrow canyon with steep vertical walls. Boaters can access the monument from Lake Powell at mile marker 45. The sampling site is located at the floating docks (fig. 4N), which can vary in location due to fluctuating reservoir levels. A marina was operated at the site through the 1970s but was closed due to sewage and fuel contamination. A floating toilet facility is provided and managed by the National Monument. The site is heavily used by boaters including tour boats and it becomes congested during the peak visitor season during the summer.

Site HU9 Padre Bay (site ID 370321111171700). - This sentinel sampling site is located in a large bay at about mile marker 23 where boating activity is high (fig. 1). The Padre Bay is a wide exposed area of Lake Powell and the site is easily identified by Dominquez Butte, which is a major landmark on Lake Powell (fig. 4O). Water depths at this site are several hundred feet depending on the reservoir level because the site is near the original Colorado River arm.

Site HU10 Warm Creek Bay (site ID 370333111262700). Warm Creek is a tributary to Lake Powell that forms a bay because of the physical characteristics of the canyon in this area. It is an extremely high-use area due to its proximity to marinas, boat ramps, and Page, Arizona, and also because there are numerous camping beaches suitable for houseboats. It is located about $11 \mathrm{mi}$ upstream of Wahweap Marina (site M4, fig. 1). Warm Creek Bay supports a GLCA-serviced floating toilet and the sampling site is adjacent to this facility several hundred feet to the east (fig. $4 P$ ).

Site HU11 Lone Rock Beach (site ID 370107111320500). Lone Rock Beach is a primitive camping area and is located

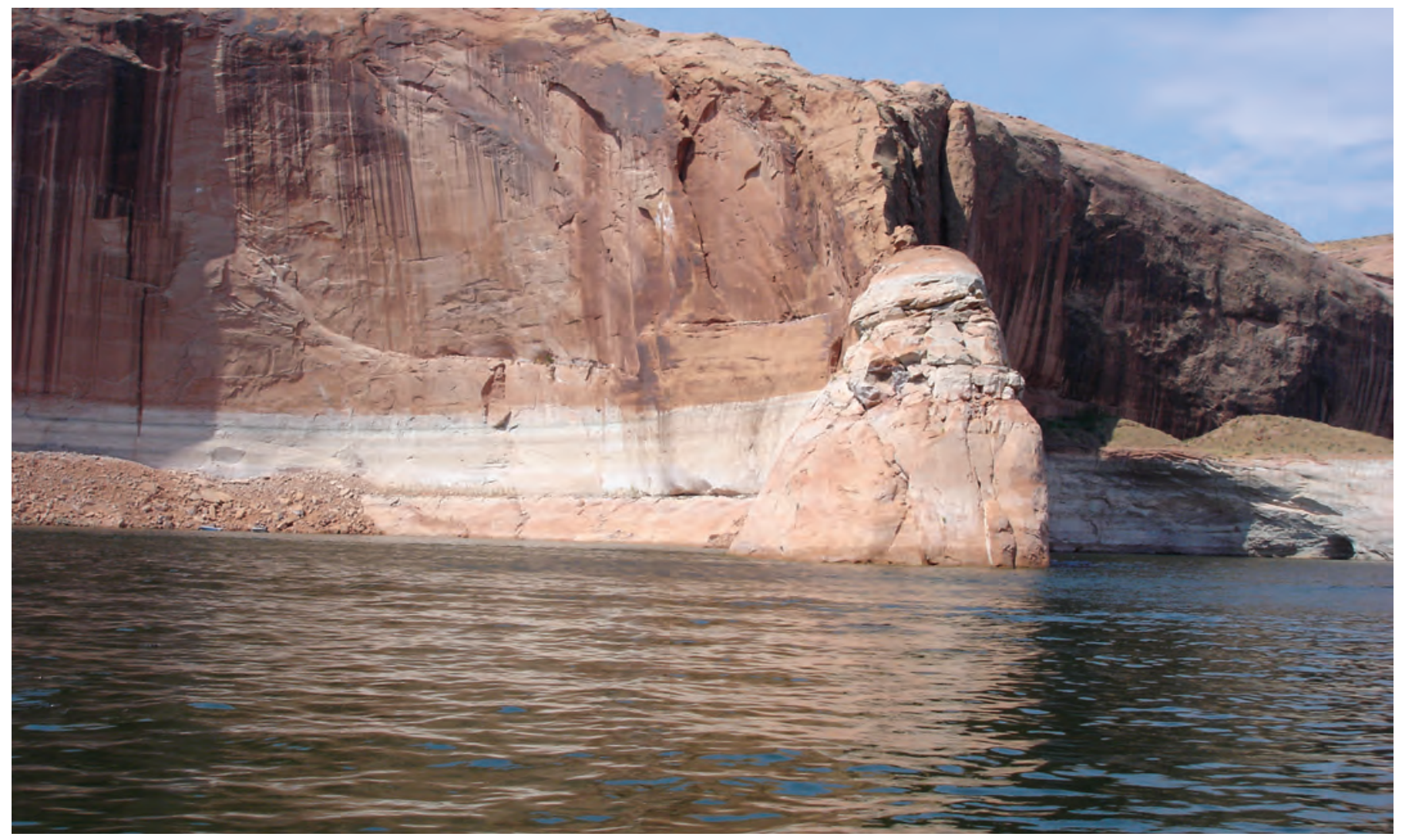

Figure 4K. Photograph of site HU5 Moqui Canyon (site ID 372838110372000). View is to the northeast. Summer 2005. 


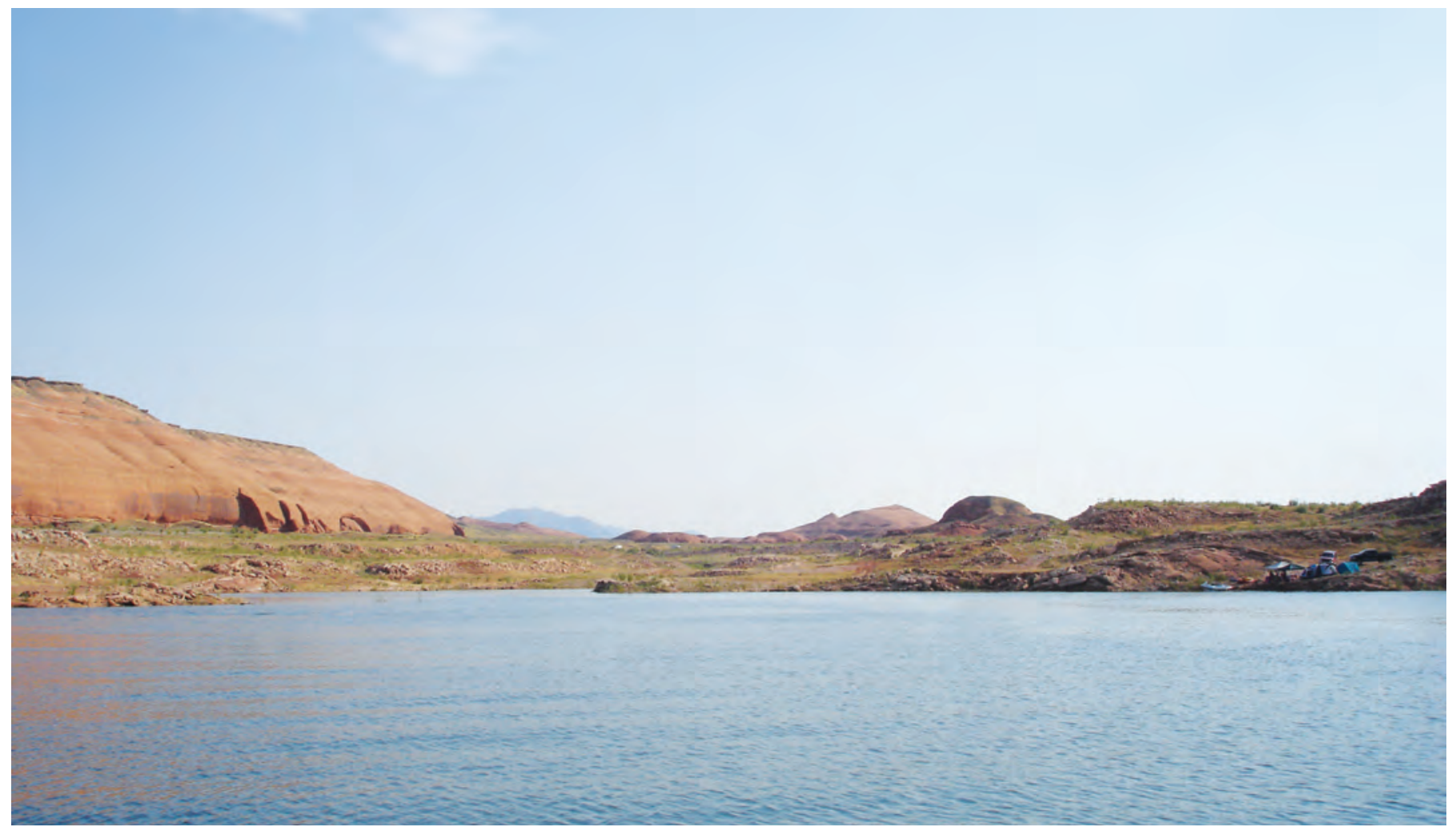

Figure 4L. Photograph of site HU6 Stanton Creek (site ID 372940110421600). View is looking to the northeast. Summer 2005.

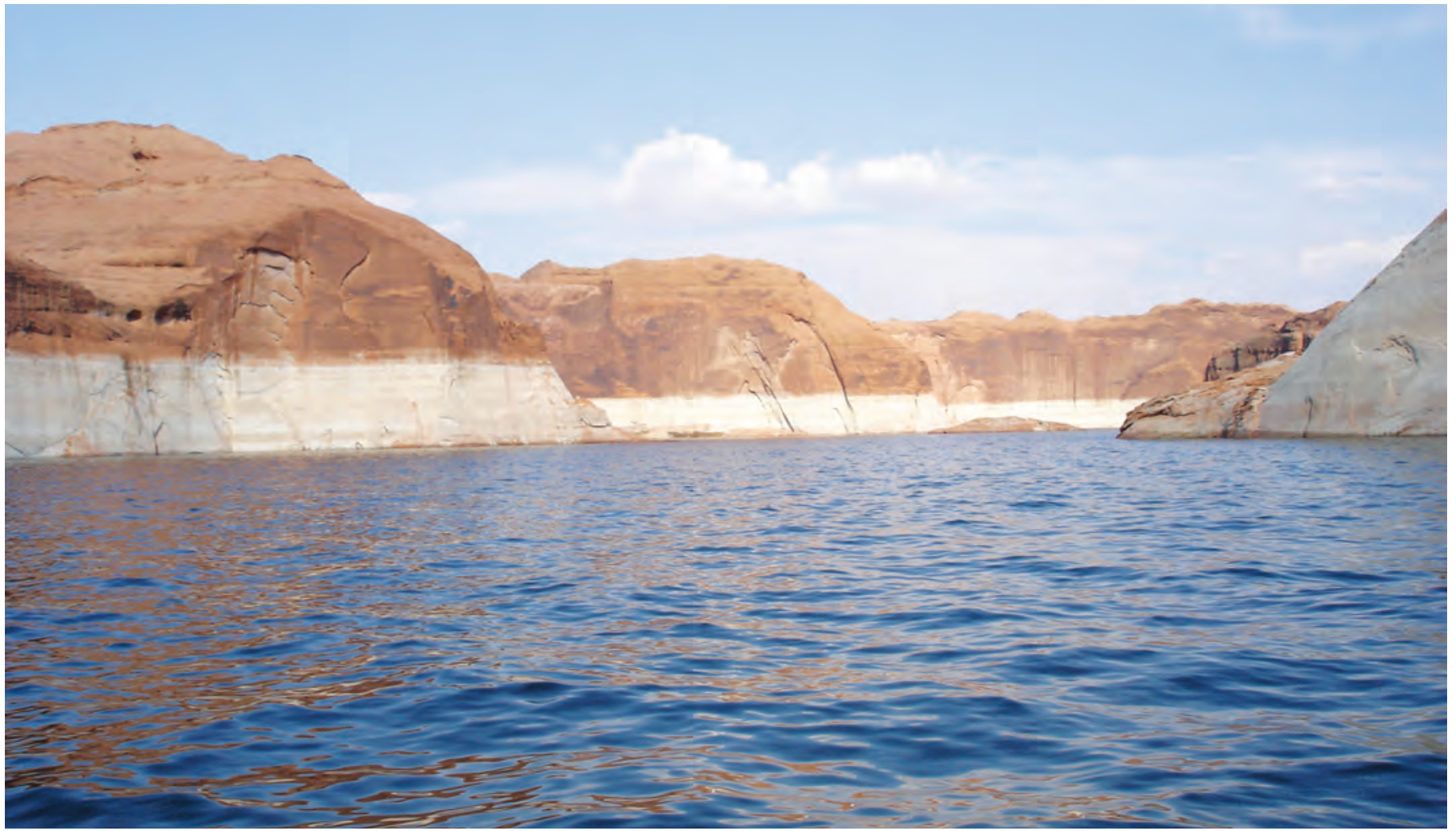

Figure 4M. Photograph of site HU7 Escalante River below 50-Mile Canyon (site ID 371938110553700) sampling area. View is looking upstream to the northwest toward 50-mile canyon. Summer 2005. 


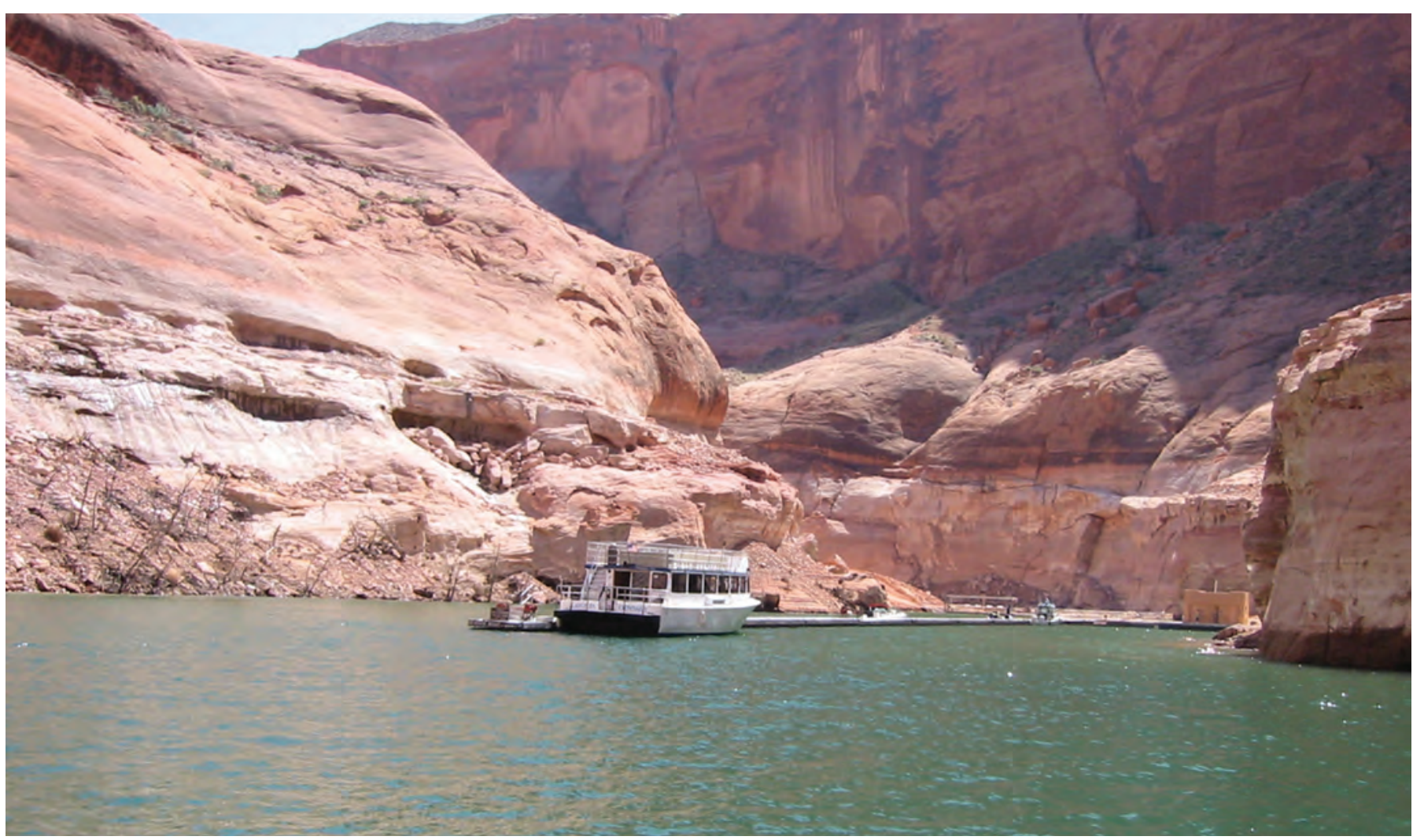

Figure 4N. Photograph of site HU8 Rainbow Bridge National Monument (site ID 370506110581600). View is to the south. Summer 2004.

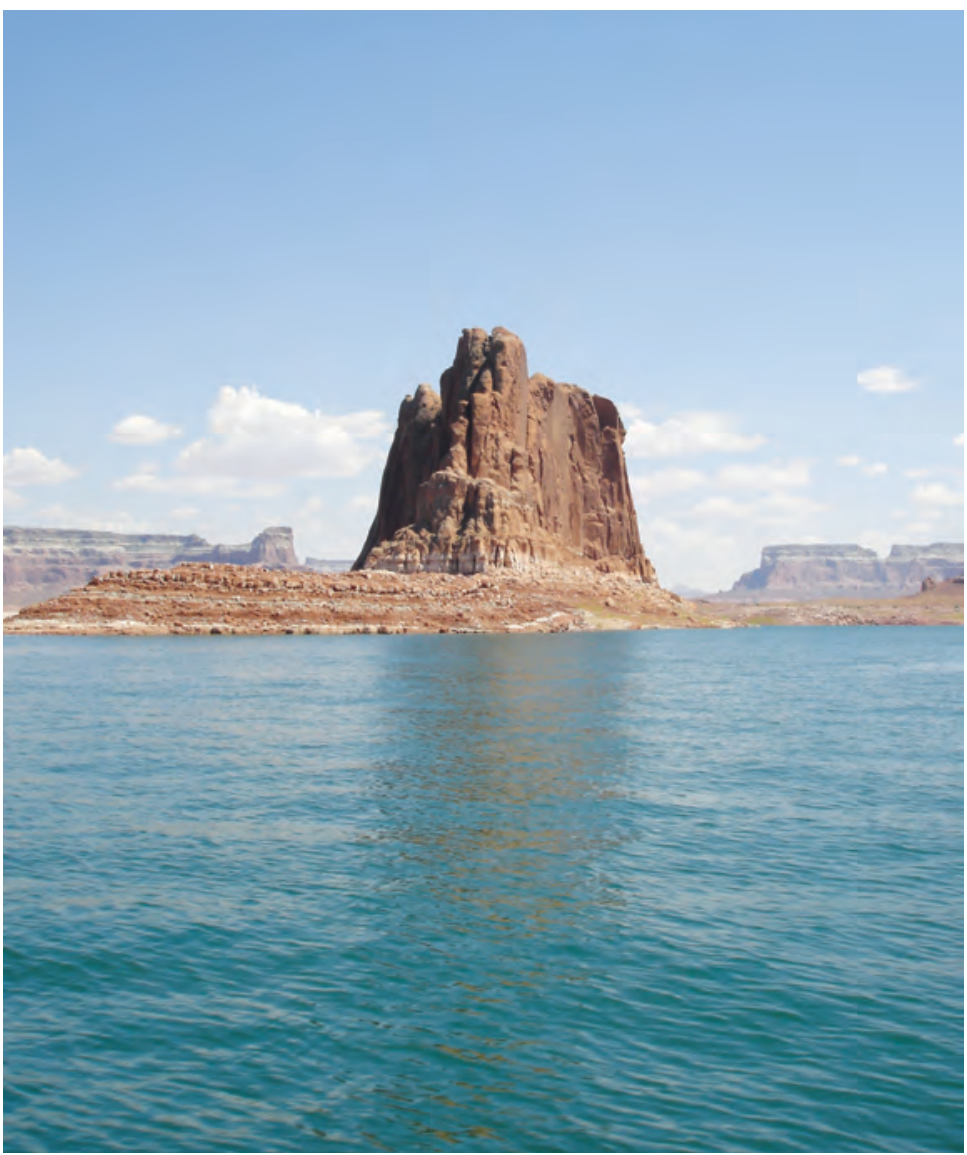

Figure 40. Photograph of site HU9 Padre Bay (site ID 370321111171700) sampling area. View is looking to the east. Summer 2005. 
at about 3 mi upstream of Wahweap Marina and is accessible by boat and also by vehicle from U.S. Highway 89 . It is the most populated and accessible beach on Lake Powell during high-use periods and it often has hundreds of visitors at a time. GLCA allows campers, including recreational vehicles, use of All-Terrain Vehicles (ATVs), direct boat access to camping sites, and open fire pits. The sampling site is several hundred feet from the beach shore to the northeast (fig. 4Q). Because of its high use, the GLCA monitors for bacteria outbreaks on a routine basis as part of their beach monitoring program (National Park Service, 2012).

\section{Site $I 18$ Colorado River inflow (site ID}

375048110244100). - The Colorado River inflow site is located near the former marina at Hite, Utah, about mile marker 139 (fig. 1). Due to declining reservoir levels, Hite no longer provides marina service but it does have launch ramps. It is unknown if marina services will be provided in the future if reservoir levels rise to a sufficient level. The exact sampling location at this site can vary somewhat depending on the elevation of the lake but generally is just downstream of the inflow of the Dirty Devil River (fig. $4 R$ ).

\section{Site I19 San Juan River Inflow (site ID}

371429110382000). - The San Juan River is a major tributary to Lake Powell, and along with the Colorado River arm, defines the general character of the shoreline of the Lake Powell (fig. 1). Like the Escalante River inflow site (I20), the location of the sampling site can vary depending on the elevation of the reservoir. The general location of the sampling site (fig. 4S) is upstream of Zahn Bay (fig. 1), more than 45 mi from the mouth of the San Juan River at mile marker 58. The visual characteristics (water clarity) of this site are considerably different from the other Lake Powell sentinel sampling sites due to the rock types that are exposed and characteristics of the San Juan River drainage basin. For example, water transparency as determined from Secchi disk measurements is limited at the sampling location. Because

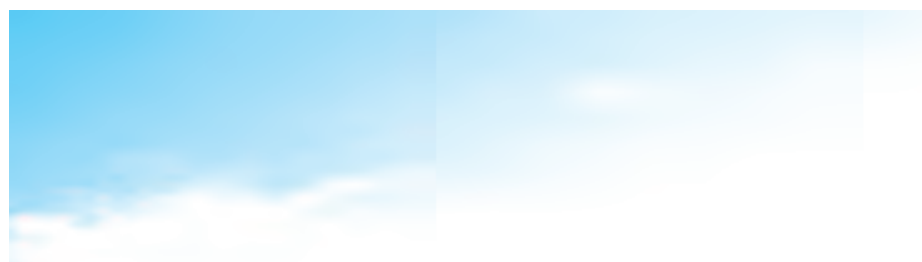

Figure 4P. Photograph of site HU10 Warm Creek Bay (site ID 370333111262700) sampling area. View is to the south. Summer 2005.

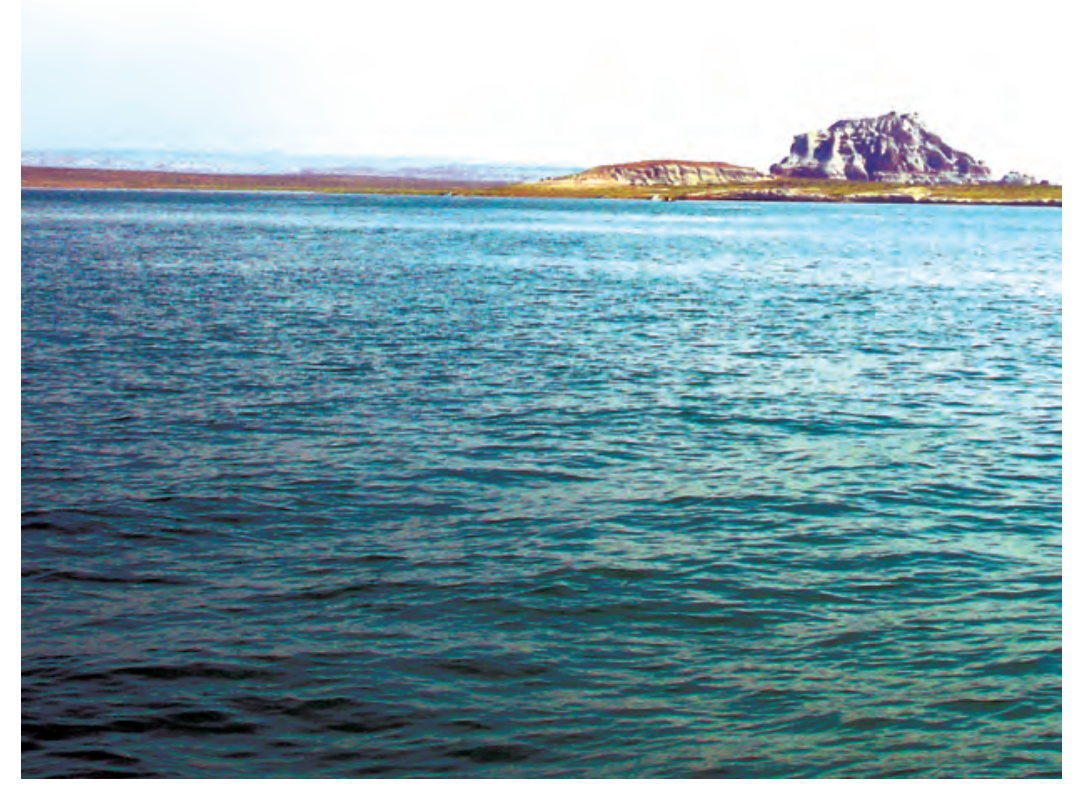




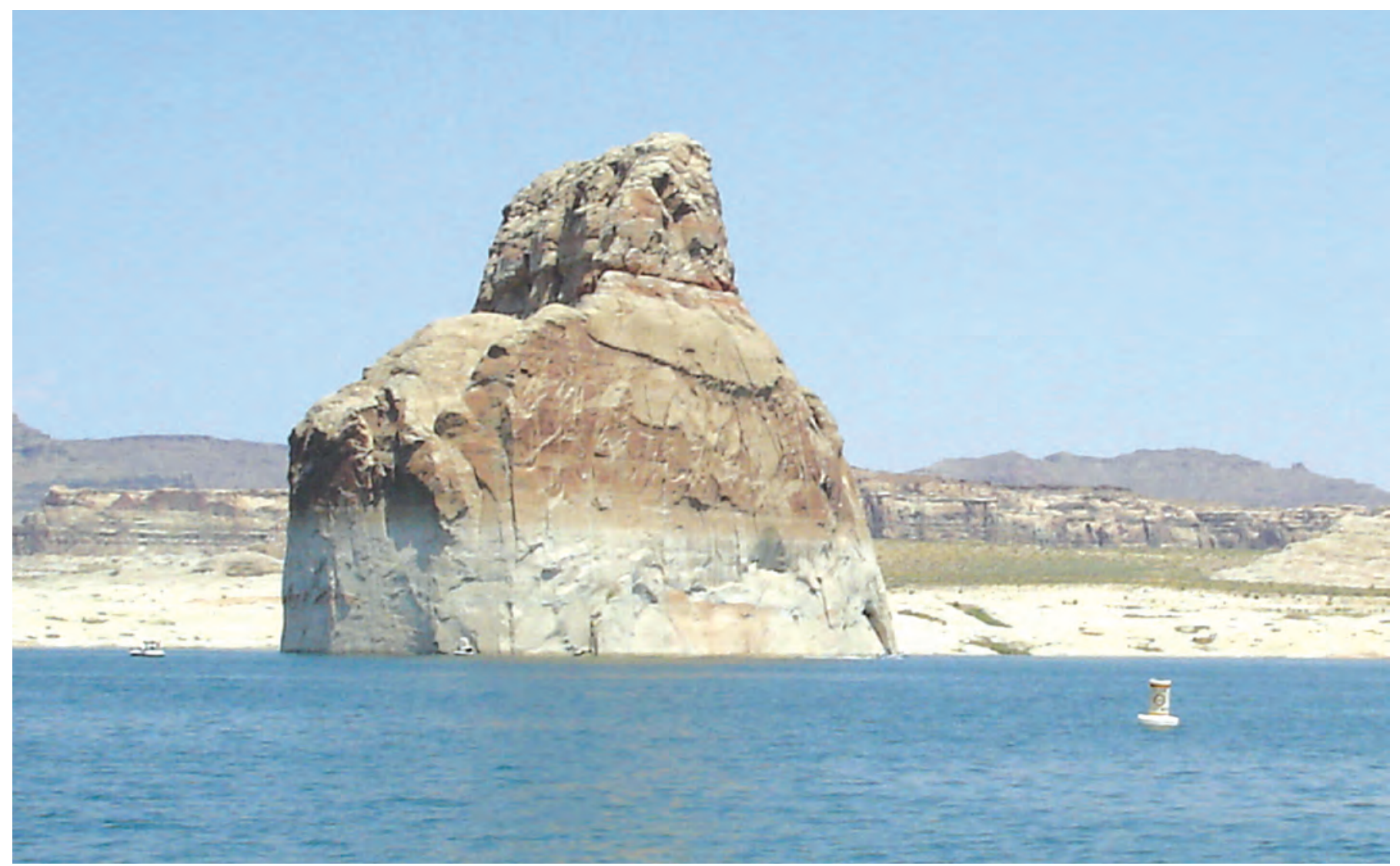

Figure 40. Photograph of site HU11 Lone Rock Beach (site ID 370107111320500) sampling area. View is looking toward the north. Summer 2011.

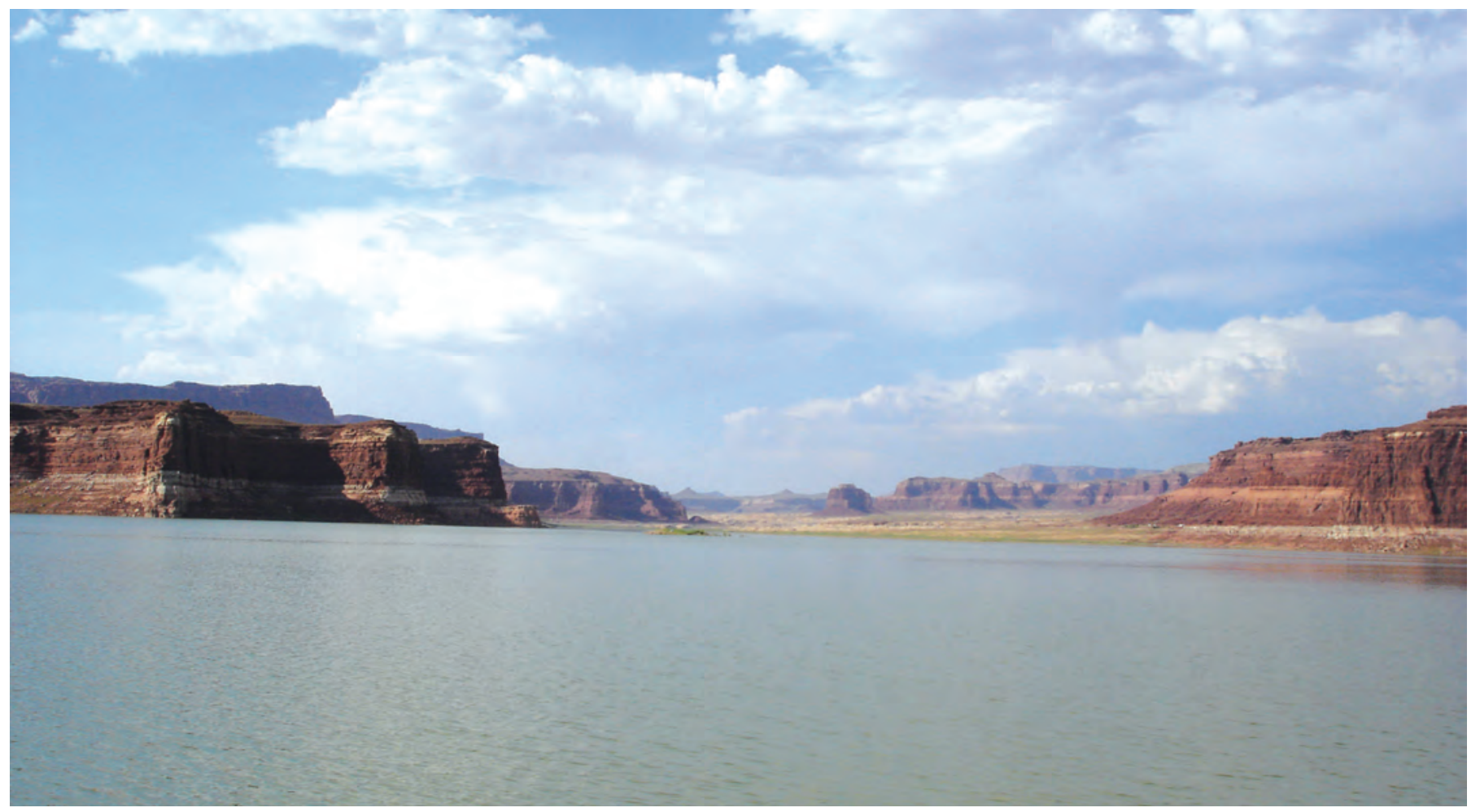

Figure 4R. Photograph of site 118 Colorado River Inflow (site ID 375048110244100). View is upstream, photo taken 2005. 
of the distance from marinas, the San Juan River inflow site is not as heavily used by recreationists compared to the other areas of Lake Powell.

\section{Site I20 Escalante River Inflow (site ID}

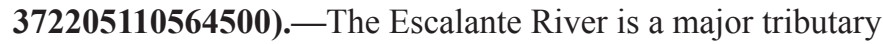
to Lake Powell and when Lake Powell is at its full pool level of 3,700 $\mathrm{ft}$, the lake can inundate more than $20 \mathrm{mi}$ of the creek's channel upstream from its mouth (fig. 1). This side canyon also consists of numerous tributary canyons that are suitable for recreation and houseboat camping. It is a popular location for visitors who access Lake Powell from Bullfrog or Halls Crossing Marinas, which are about 38 mi upstream of the mouth of the Escalante River. The inflow sampling site is several miles upstream of site HU7 (Escalante River at 50-Mile Canyon). Sampling at this particular sentinel site may change depending on accessibility related to the level of the reservoir and hazards, such as floating debris (fig. 4T).

\section{Methods}

\section{Field Methods}

Discrete measurements (point samples) of water temperature, specific conductance, and $\mathrm{pH}$ of shallow water (about $1 \mathrm{~m}$ below the water surface) were made at all sampling locations during specific times following the methods described by Wilde and Radtke (1998). Various water-quality instruments were used to measure the discrete parameters and these instruments were calibrated and verified on a daily basis.

A 20-cm diameter Secchi disk was used to measure the transparency of water. Secchi-disk measurements were made from the shaded side of the boat when profile measurements and water samples were being collected. The disk was lowered through the water column until it was no longer visible, and the depth of the disk was recorded. This process was repeated three times, and the average value recorded. For more information about the Secchi disk, see Cole (1975, p. 116-118).

Vertical water chemistry and physical properties control the distribution of living or nonliving materials dissolved or suspended (Marzolf and others, 1998), and therefore it is important to select representative depths for collecting water samples based on the lakes stratification at each sentinel site. A Sea-Bird Electronics, Inc. (SBE), model SBE25 ${ }^{\mathrm{TM}}$ CTD (conductivity, temperature, and depth) profiler was used to make depth-profile measurements for determining the depth at which water samples should be taken (fig. $5 A$ ). The SBE25 ${ }^{\mathrm{TM}}$ CTD measures pressure, water temperature, specific conductance, $\mathrm{pH}$, dissolved-oxygen concentration, and turbidity. Pressure measurements are converted to depths. All sensors of the SBE25 ${ }^{\mathrm{TM}}$ CTD were calibrated annually by the

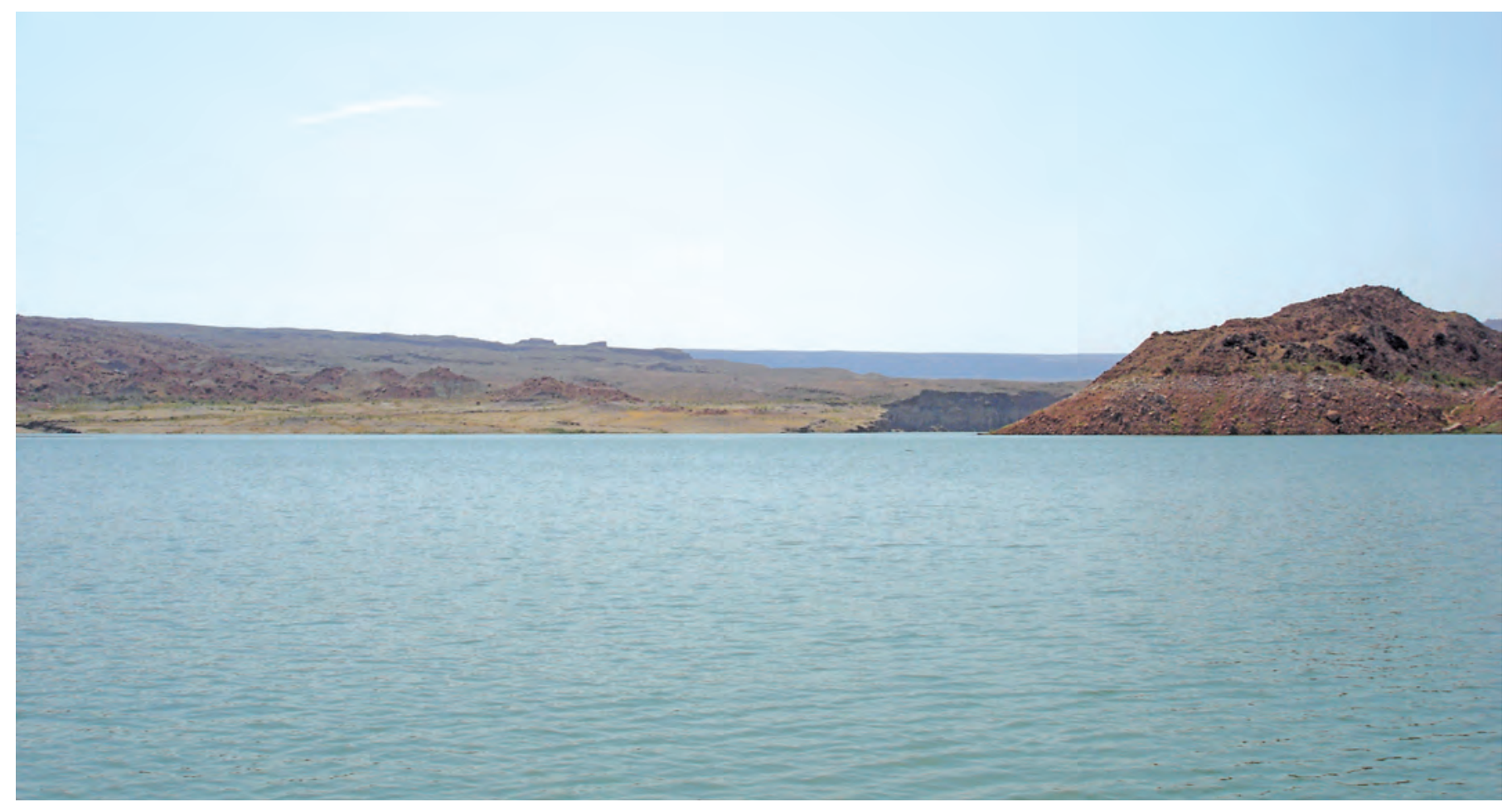

Figure 4S. Photograph of site I19 San Juan River Inflow (site ID 371429110382000) sampling area. View is looking upstream to the northeast. Summer 2005. 
manufacturer and calibration coefficients were updated in the Sea-Bird software following calibration.

The SBE25 ${ }^{\mathrm{TM}}$ CTD was programmed to scan the sensors 8 times per second. The data were logged as raw voltages from the sensors in hexadecimal format. Profile measurements were accomplished in about 10 minutes with a downcast descent rate of about $3 \mathrm{ft} / \mathrm{s}$. Start time of the downcast and other information pertinent to the measurement site were entered into the Sea-Bird software for site identification purposes.

Following the collection of the downcast measurements, the raw hexadecimal data were converted using Seabird software (SBE Data Processing 7.2f; Sea-Bird Electronics, Inc., 2012), to values of pressure, depth, water temperature, $\mathrm{pH}$, specific conductance, dissolved-oxygen concentrations, and turbidity, as ASCII numbers in engineering format. These converted values were then bin averaged into $1 \mathrm{~m}(3.281 \mathrm{ft})$ "bins." The raw hexadecimal data are available, but the SeaBird processing software is needed for data conversion.

Water samples for major ions, nutrients, organic carbon, and trace element analyses were collected using a polytetrafluroethylene (PTFE) fixed-bottle sampler (a sampler designed to collect point samples at a specified depth; fig. $5 B$ ). This sampler was suspended by a calibrated line to determine sampling depth and was weighted on the bottom by a $5-\mathrm{kg}$ epoxy-coated weight. The bottle was sealed with a precleaned silicone-rubber stopper attached to a Spiderwire ${ }^{\mathrm{TM}}$ braided (nonstretchable) fishing line. When reaching the predetermined water depth, the stopper was rapidly removed by retrieval of the fishing line. After the bottle filled at the specified depth, the sampler was raised to the surface and removed from the lake. Sample water was decanted from the fixed-bottle sampler into a 1-L PTFE holding bottle. A summary of data available at the sentinel sites is shown in table 1 .

Sample water from the 1-L PTFE holding bottle was processed as follows:

- Subsamples were filtered through a deionized-water rinsed, $0.45-\mu \mathrm{m}$ pore-size, polysulfone cartridge filter into a $30-\mathrm{mL}$ dark polyethylene bottle for nutrient determinations, a preburned $60-\mathrm{mL}$ glass bottle for dissolved organic carbon determination, and a 60-mL polyethylene bottle for anion determinations. These samples were unpreserved and chilled during transport to the laboratory for analysis.

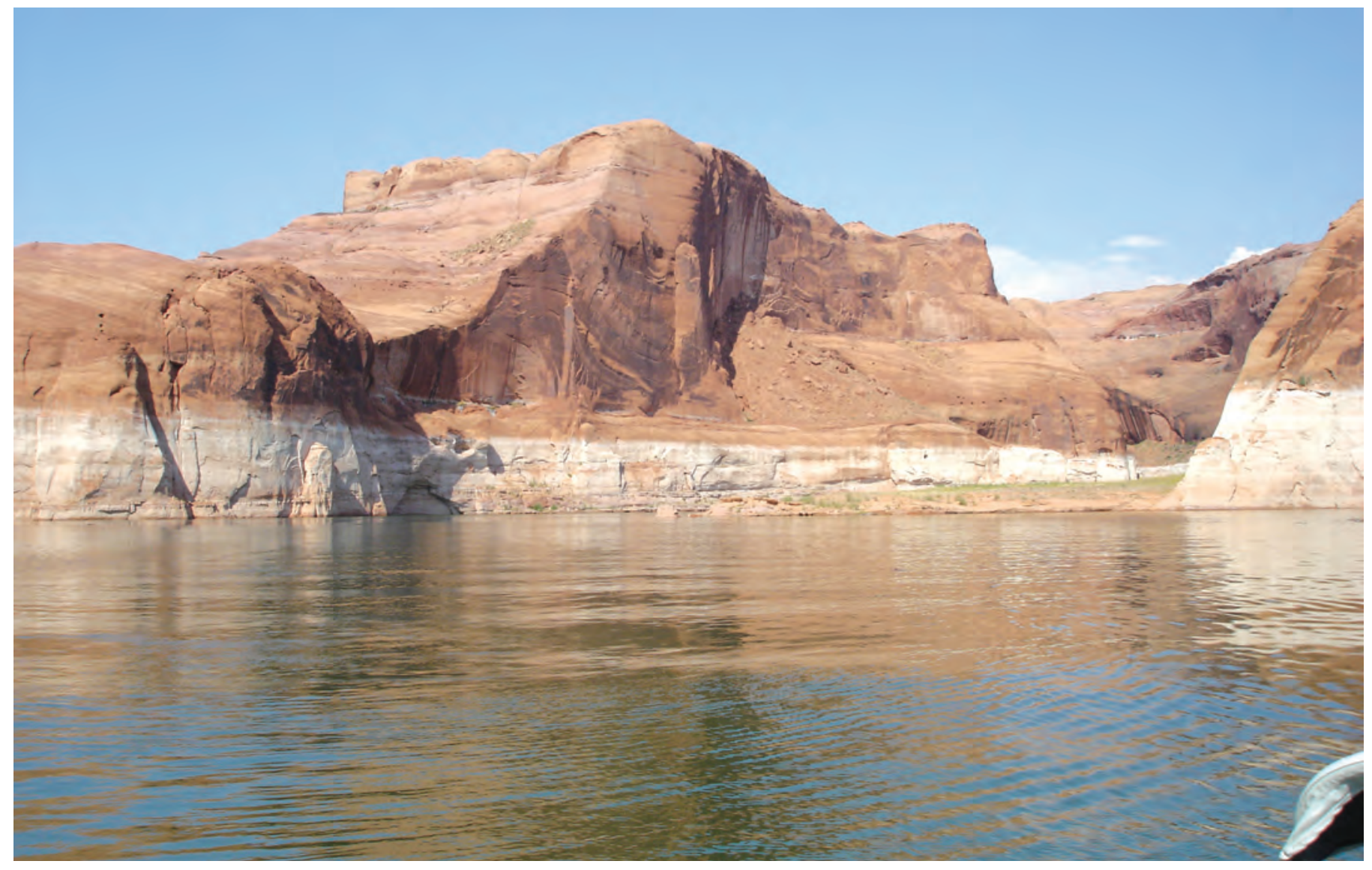

Figure 4T. Photograph of site I20 Escalante River Inflow ( site ID 372205110564500). Site is looking upstream to the northeast. Summer 2005. 

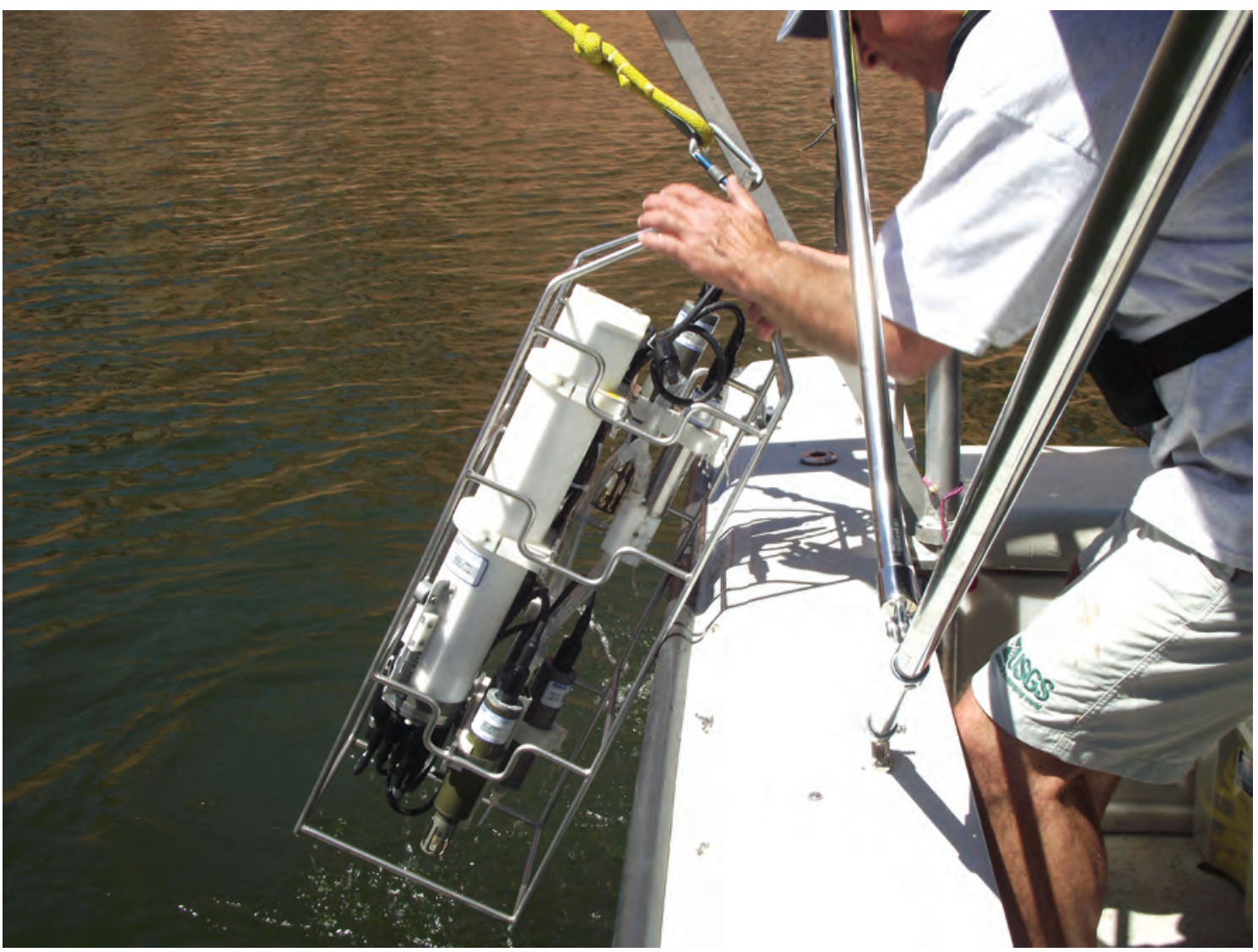

Figure $\mathbf{5 A}$. Photograph of the SBE25 profiler.

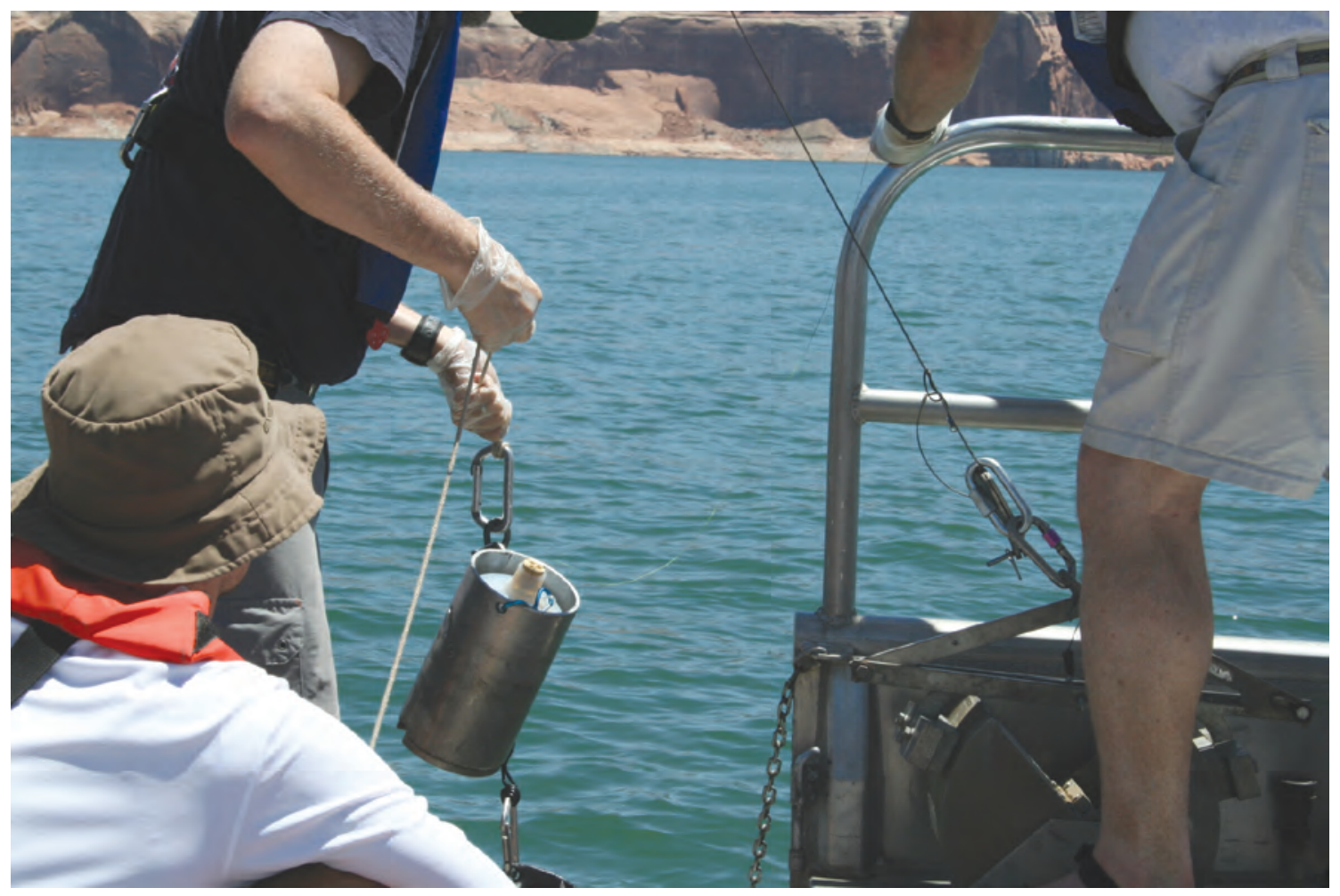

Figure 5B. Photograph of National Research Program (NRP) water sampler. 
- An aliquot of sample from the holding bottle for dissolved trace element determinations was filtered through a $0.40-\mu \mathrm{m}$ pore-size Nuclepore ${ }^{\mathrm{TM}}$ polycarbonate-membrane filter, using a vacuum filter apparatus made from PTFE (Kelly and Taylor, 1996). The following steps were used to minimize contamination: (1) the filter apparatus was thoroughly cleaned and rinsed with deionized water; (2) a new $0.40-\mu \mathrm{m}$ pore size, 47 -mm-diameter, polycarbonate-membrane filter was placed on the filter support and precleaned by drawing approximately $50 \mathrm{~mL}$ of 0.1 percent (volume/ volume) ultrapure nitric acid $\left(\mathrm{HNO}_{3}\right)$ rinse solution through the filter into a waste bottle; (3) about $25 \mathrm{~mL}$ of a subsample of the composite was then filtered to prerinse the sample receiving bottle and discarded (this step also effectively preloaded the filter with particulates); (4) the balance of the subsample was filtered into a $125-\mathrm{mL}$ polyethylene sample bottle; and (5) the filtered sample was preserved with the addition of $1 \mathrm{~mL}$ of concentrated ultrapure $\mathrm{HNO}_{3}$, to a pH less than 2 using a PTFE dispensing bottle (Brinton and others, 1995). Only one filter membrane was used for the entire filtration process per sample.

- A second aliquot from the same filtration process was used for the preparation of a sample for total dissolved mercury $(\mathrm{Hg})$ determination. The filtrate for this sample was collected in an acid-rinsed borosilicate glass bottle. A $5-\mathrm{mL}$ mixture of high purity potassium dichromate $\left(\mathrm{K}_{2} \mathrm{CrO}_{7}\right)$ and ultrapure $\mathrm{HNO}_{3}$ was added to $125 \mathrm{~mL}$ of the sample, resulting in a final concentration of 0.04 percent (weight/volume) $\mathrm{K}_{2} \mathrm{CrO}_{7}$ and 4 percent (volume/volume) $\mathrm{HNO}_{3}$.

Water samples for VOC (volatile organic compounds) analyses were collected using a sampler designed and built by Wildco $^{\mathrm{TM}}$ for the USGS National Water-Quality Assessment Program (NAWQA; fig. 5C). The sampler is designed to collect a sample at a single point. The stainless-steel sampler holds four $40-\mathrm{mL}$ vials. Copper tubes extend to the bottom of each vial from the inlet ports on top of the sampler. The vials fill and overflow into the sampler body, displacing the air in the vials and in the sampler through the exhaust tube. The total volume of the sampler is eight times larger than the vials; therefore, the vials are flushed seven times (removing the air) before the final volume is retained in the vial. The small (1/16-in. inside diameter) copper inlet ports result in a slow (3-4 minutes) filling time helping to produce a representative sample and allowing sufficient time to place the sampler at the desired depth. The sampler begins to fill as soon as it enters the water; however, the final sample is retained in the vial during the last $15-20$ seconds of the filling process. A cover over the inlet ports prevents contamination from surface oil and debris when the sampler is removed from the water (Shelton, 1997). The sampler was lowered approximately 1.5 $\mathrm{ft}$ below the water surface and held in place while the sampler simultaneously filled the 4 replicate $40-\mathrm{mL}$ vials. Each vial of sample was then preserved by the addition of 2 drops of concentrated hydrochloric acid $(\mathrm{HCl})$. The vials were then immediately sealed without headspace.

Raw water samples were collected directly in 1-L amber glass bottles baked at $450^{\circ} \mathrm{C}$ for oil and grease and total petroleum hydrocarbons (TPH) analysis and were preserved by the addition of $10 \mathrm{~mL}$ of concentrated sulfuric acid to each
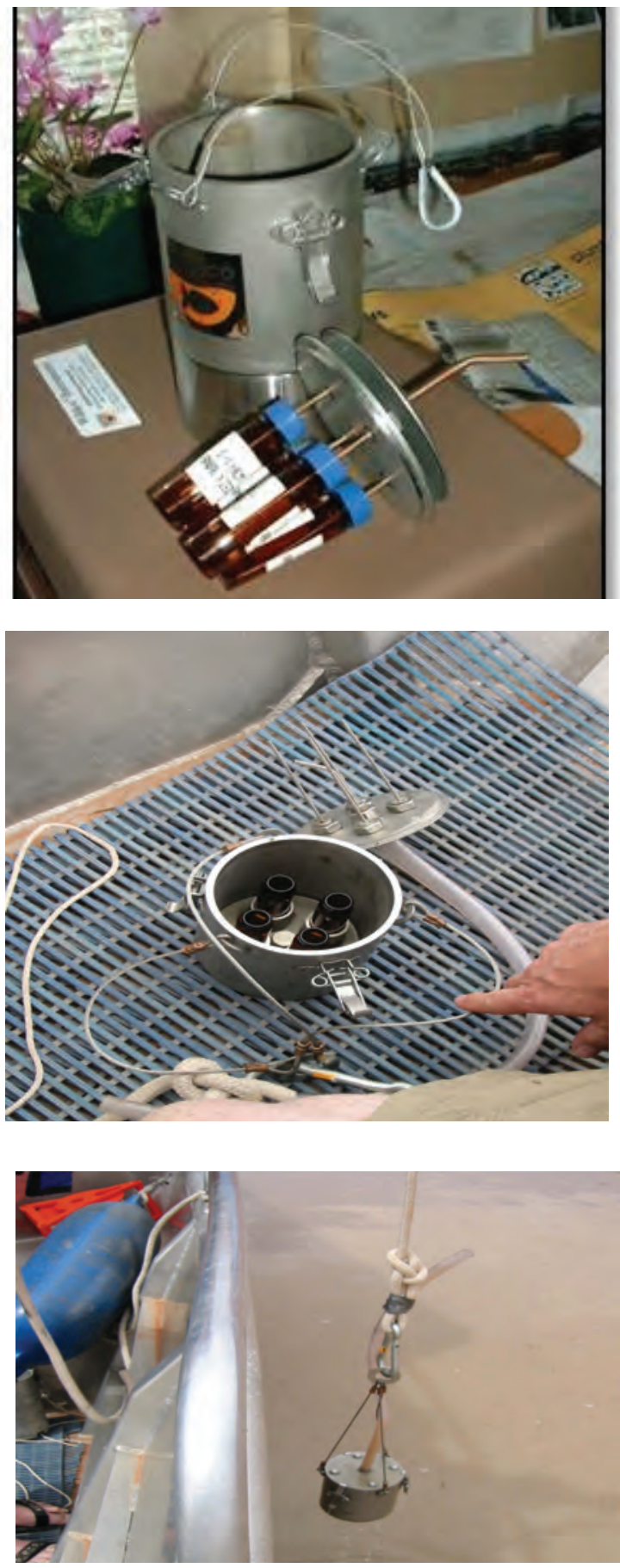

Figure 5C. Photographs of the volatile organic compounds (VOC) sampler. 
1-L amber glass bottle. All samples for organic determinations were chilled to $4{ }^{\circ} \mathrm{C}$ for transport to the laboratory for analysis.

Lakebed material was collected using a Ponar ${ }^{\mathrm{TM}}$ dredge (fig. 5D) and following protocols described by Radtke (1997). The dredge was lowered and triggered to collect a surface sample of the lakebed material for analysis. A Teflon ${ }^{\mathrm{TM}}$ spatula or spoon was used to collect a sample from the dredge and transferred to a pre-cleaned wide-mouth glass jar. Care was given to collect a representative sample from the dredge that was not in contact with the metal sampler. Approximately $1-\mathrm{kg}$ of wet sediment was collected from each selected site and stored chilled (less than $4{ }^{\circ} \mathrm{C}$ ).

\section{Laboratory Methods}

Water samples were analyzed by two laboratories: (1) the USGS National Research Program Laboratory (NRP) in Boulder, Colorado and (2) the USGS National Water Quality Laboratory (NWQL) in Lakewood, Colorado. Water samples collected for analyses of all dissolved constituents were analyzed directly from sample bottles (preserved after sample processing) with no further pretreatment.

Major cations of calcium $(\mathrm{Ca})$, magnesium $(\mathrm{Mg})$, sodium (Na), and silica $\left(\mathrm{SiO}_{2}\right)$, were analyzed at the USGS National Research Laboratory in Boulder, Colorado, and were determined by inductively coupled plasma-atomic emission spectrometric (ICP-AES) techniques using a Perkin Elmer Optima $3300^{\mathrm{TM}}$, dual-view emission spectrometer operating in the axial-view mode (Garbarino and Taylor 1979; Mitko and Bebek, 1999). Iron (Fe), phosphorus (P), and sulfur (S) also were determined by using this technique. Potassium (K) was determined by an ICP-AES technique using the same instrumentation operating in the radial-view mode. All samples were determined in triplicate to provide a measure of analytical variability.

Anions, including chloride $(\mathrm{Cl})$, nitrate $\left(\mathrm{NO}_{3}\right)$, and sulfate $\left(\mathrm{SO}_{4}\right)$, were determined by ion chromatography (Brinton and others, 1996). Other nutrients, including ammonium $\left(\mathrm{NH}_{4}\right)$, nitrite $\left(\mathrm{NO}_{2}\right)$, and phosphate $\left(\mathrm{PO}_{4}\right)$, were determined by an automated spectrophotometric absorption method described by Antweiler and others (1996).

Total alkalinity was determined on unpreserved filtered samples by an automated Gran titrimetric procedure using sulfuric acid as the titrant (Skougstad and others, 1979). Alkalinity and $\mathrm{pH}$ data were used to calculate concentrations of carbonate and bicarbonate. Dissolved-organic carbon was determined by persulfate oxidation of the organic carbon in the sample to carbon dioxide, which was measured using an infrared absorption spectrophotometric technique described by Wershaw and others (1987).

Trace-element determinations (see list at the beginning of this report), excluding $\mathrm{Hg}$, were analyzed at the USGS National Research Laboratory in Boulder, Colorado, using a Perkin Elmer Elan Model $6000^{\mathrm{TM}}$ inductively coupled plasmamass spectrometer (ICP-MS). Aerosols of aqueous samples
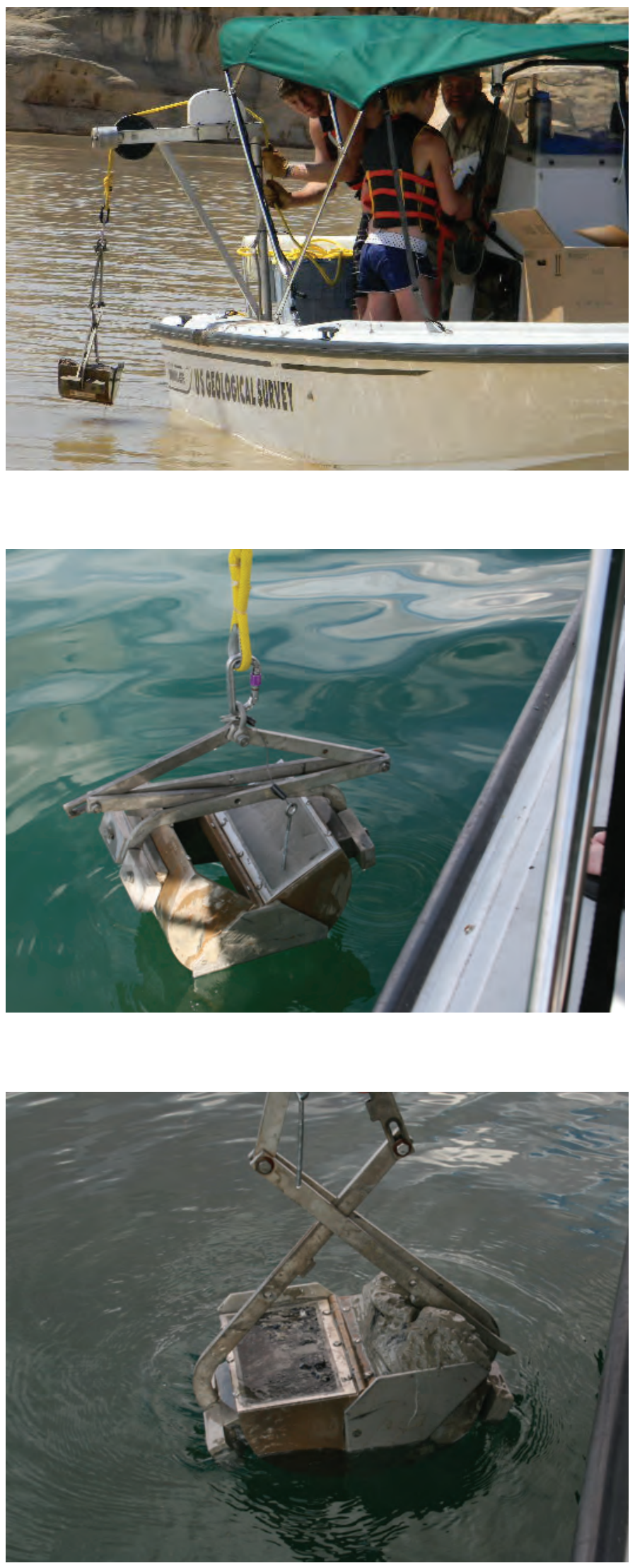

Figure 5D. Photographs of the Ponar dredge sampler. 
acidified with $\mathrm{HNO}_{3}$ were introduced into the spectrometer with a pneumatic nebulizer. Multiple internal standards (indium, iridium, and rhodium) covering the entire element mass range were used to normalize the system for drift. Details of the specific analysis techniques, procedures, and instrumental settings are described in Garbarino and Taylor (1994) and Taylor (2001).

Trace concentrations of dissolved $\mathrm{Hg}$ were measured using an automated cold-vapor atomic fluorescence spectrometric (PS Analytical) technique. Details of the method are described in Roth (1994) and Roth and others (2001). Elemental $\mathrm{Hg}$ vapor from the samples was produced by chemically reducing $\mathrm{Hg}$ in the samples with excess stannous chloride. The resulting vapor was transported to the atomic fluorescence detector with a stream of argon gas for quantitative measurement.

Samples collected for VOC determinations were analyzed by the USGS National Water Quality Laboratory (NWQL) using purge-and-trap gas chromatography/mass spectrometry methods described in Connor and others (1998). Concentrations of oil and grease were determined by the NWQL using USEPA Method 1664 (U.S. Environmental Protection Agency, 1999), which is a gravimetric determination of $n$-hexane extractable material. Concentrations of TPHs also were determined by the NWQL using the same extraction procedure followed by a silica gel separation.

Lakebed material was analyzed by the USGS NWQL for polycyclic aromatic hydrocarbons (PAHs). Samples were chilled to $4{ }^{\circ} \mathrm{C}$ and shipped to the NWQL for analysis as described by Furlong and others (1996). This method involves preconcentration of the sample by solvent extraction, separation by gel chromatography, and measurement by gas chromatography/mass spectrometry.

\section{Quality of Water and Sediment Data}

All inorganic laboratory sample determinations made at the USGS National Research Program Laboratory in Boulder, Colo., for major ions, trace elements, and nutrients were randomly performed in triplicate, throughout each analysis session. After statistical evaluation, outliers were rejected or samples were rerun until quality control objectives were satisfactorily met. Error terms representing the precision (1 standard deviation) of the analytical laboratory determinations are reported with each measurement. Calibration curves for instrumental determinations were established by the use of at least five separate concentration calibration standards, prepared gravimetrically from pure metals or metal salts. Laboratory reagent blanks and field process blanks were analyzed when appropriate and used to evaluate the integrity of sample determinations.

The NWQL analyzed reagent water blanks and reagent water spikes with each set of organic wastewater-compound analyses to monitor the method performance as part of the laboratory quality control. Duplicate water samples were collected during 2004-06 to check the replication of results produced by the laboratory.

Measurement precision or variability is evaluated by the analysis of field replicates. During the study, water samples were collected in replicate for organic and inorganic analysis from eight sites including all the marina sites (M1, M2, M3, M4, M5, and M6) and two high-use sites (HU7 and HU8), processed in the field, and transported to the laboratory and analyzed under identical conditions. Because of concern regarding the possible sample contamination from the boat engines during the sampling for VOC determinations, a blank sample was collected from the opposite side of the boat from where samples were collected, with the boat engines idling. Results of the analysis of this blank showed no measurable concentrations of any of the VOC constituents greater than the detection limit of $0.2 \mu \mathrm{g} / \mathrm{L}$. Duplicate and blank samples also were collected for VOCs, oil and grease, and TPH. For additional information on quality control of data, see Hart and others (2004).

\section{Water and Sediment Data}

All data collected during 2004-06 are provided in Microsoft $^{\circ}$ Excel spreadsheets in appendixes A-F. Appendix A includes discrete measurements of water temperature and specific conductance that were made from surface samples, along with measurements of water clarity using a Secchi disk. Appendixes B-E include all chemical analyses (water phase and lakebed material), including major ions, nutrients, organic carbon (appendix B), trace elements (appendix C), organic compounds including TPH, oil and grease, and VOCs (appendix D), and PAHs in lakebed material collected from 4 of the 20 sentinel sampling sites (appendix E). The bin-averaged SBE25 profile data are included in appendix F.

\section{Future Sampling Plans}

The sentinel sites will be used as long-term monitoring sites for the Glen Canyon (GLCA) NRA based on a monitoring plan prepared by the National Park Service (2004). Most recently, sentinel sites were sampled during 2010 and 2011. Semi-permeable membrane devices (SPMDs) were deployed at all 20 sentinel sites. The SPMDs will provide some insight to the potential for polycyclic aromatic hydrocarbons (PAHs) to bioconcentrate in fatty tissue aquatic life. During this same time period, sediment cores also were collected from the San Juan River inflow area (2010) and from the Escalante River inflow area (2011). Analyses of data for these studies are currently being evaluated. 


\section{Summary}

During the spring of 2004 and summers of 2005 and 2006, the U.S. Geological Survey and National Park ServiceGlen Canyon National Recreation Area collected baseline water and sediment chemistry data at 20 sentinel sampling sites on Lake Powell. The sentinel sampling sites are locations where repeat sampling and measurements can be made over time, to monitor the effects of visitor use on the quality of water and sediments and biota in Lake Powell. Previous work by the U.S. Geological Survey and Glen Canyon National Recreation Area showed the effects of visitor use on the selected side canyons (high-use areas), and those results along with other factors were used to design and select the long-term monitoring sites. The sentinel sites include 6 marinas, 11 highuse sites, and 3 tributary inflow sites that span the lake from Glen Canyon Dam to Hite, Utah, a distance of about 140 lake miles.

Sampling and measurements made during the spring of 2004 provide baseline data for what is defined as a lowvisitor use period - when powerboats and personal watercraft are used minimally by visitors. Sampling and measurements were made during 2005 and 2006 during the summer months when visitation is defined as high and potential pollution from powered watercraft is at its peak.

Water samples were collected based on the structure of the water column as determined from depth-profile measurements at each sentinel site. Water temperature, specific conductance, $\mathrm{pH}$, dissolved-oxygen concentrations, and turbidity were used to evaluate the stratification of the lake and to select sampling depths. A Secchi disk was used to measure the water clarity. Water samples were analyzed for (1) major ions, nutrients, and organic carbon; (2) trace elements; (3) organic compounds including oil and grease, total petroleum hydrocarbons, and volatile organic compounds. Lakebed material was analyzed for polycyclic aromatic hydrocarbons.

\section{Acknowledgements}

The authors thank the former Glen Canyon National Recreation Area (GLCA) Superintendent, Kitty Roberts, for her support, and former GLCA biologist, Jesse Granet, for his support in the field. Without the logistical support, boats, and laboratory facilities from GLCA, the work would have been much more challenging to complete. Gratitude is expressed to USGS scientists Ronald Antweiler, David Roth, and Terry Plowman, for their contributions to field and laboratory work. A special thanks to Greg Fisk for field assistance, boat operation, and mechanical and logistical foresight.

\section{References Cited}

Antelope Point, 2011, Antelope Point and Lake Powell: Website, accessed August 3, 2011, at http://www. antelopepointlakepowell.com/.

Antweiler, R.C., Patton, C.J., and Taylor, H.E., 1996, Automated colorimetric methods for the determination of nitrate plus nitrite, nitrite, ammonium, and orthophosphate ions in natural water samples: U.S. Geological Survey Open-File Report 93-638, 23 p.

Aramark Parks and Destinations, 2010, Lake Powell Resorts and Marinas, Ferry Service: Website, accessed August 28, 2012, at http://www.lakepowell.com/ferry-service.aspx.

Brinton, T.I., Antweiler, R.C., and Taylor, H.E., 1996, Method for the determination of dissolved chloride, nitrate and sulfate in natural water using ion chromatography: U.S. Geological Survey Open-File Report 95-426A, 16 p.

Brinton, T.I., Garbarino, J.R., Peart, D.B., Taylor, H.E., and Antweiler, R.C.,1995, Concentration and transport data for dissolved inorganic constituents in water collected during seven cruises on the Mississippi River and some of its tributaries, July 1987-June 1990: U.S. Geological Survey Open-File Report 94-524, 102 p.

California Environmental Protection Agency, Air Resources Board, 1999, New regulatons for gasoling marine engines: Fact Sheet, 2 p., accessed May 1, 2012, at http://www.arb. ca.gov/msprog/offroad/recmarine/documents/facts.pdf.

Cole, G.A., 1975, Textbook of Limnology: Tempe, Arizona, Department of Zoology, Arizona State University, C.V. Mosby Company, 283 p.

Conner, B.F., Rose, D.L., Noriega, M.C., Murtagh, L.K., and Abney, S.R., 1998, Methods of analysis by the U.S. Geological Survey National Water Quality LaboratoryDetermination of 86 volatile organic compounds in water by gas chromatography/mass spectrometry, including detections less than reporting limits: U.S. Geological Survey Open-File Report 97-829, 78 p.

Federal Register, 2003, Glen Canyon National Recreation Area, PWC use: Code of Federal Regulations, 68 FR 554448, p. 55448-55466, accessed September 29, 2011, at https://federalregister.gov/a/03-24363.

Furlong, E.T., Vaught, D.G., Merten, L.M., Foreman, W.T., and Gates, P.M., 1996, Methods of analysis by the U.S. Geological Survey National Water Quality LaboratoryDetermination of semivolatile organic compounds in bottom sediment by solvent extraction, gel permeation chromatographic fractionation, and capillary-column gas chromatography/mass spectrometry: U.S. Geological Survey Open-File Report 95-719, 67 p. 
Garbarino J.R., and Taylor, H.E., 1979, An inductively coupled plasma-atomic emission spectrometric method for routine water quality testing: Applied Spectroscopy, v. 33, p. 220-226.

Garbarino, J.R., and Taylor, H.E., 1994, Inductively coupled plasma-mass spectrometric method for the determination of dissolved trace elements in water: U.S. Geological Survey Open-File Report 94-358, 92 p.

Hart, R.J., Taylor, H.E., Antweiler, R.C., Fisk, G.G., Anderson, G.M., Roth, D.A., Flynn, M.E., Peart, D.B., and Barber, L.B., 2004, Physical and chemical characteristics of Knowles, Forgotten, and Moqui Canyons, and effects of recreational use on water quality, Lake Powell, Arizona and Utah, U.S. Geological Survey Scientific Investigations Report 2004-5120, 43 p.

Hart, R.J., Taylor, H.E., Antweiler, R.C., Graham, D.D., Fisk, G.G., Riggins, S.G., and Flynn, M.E., 2005, Sediment chemistry of the Colorado River Delta of Lake Powell, Utah, 2001: U.S. Geological Survey Open-File Report 2005-1178, $33 \mathrm{p}$.

Kelly, T., and Taylor, H.E., 1996, Concentrations and loads of specific trace elements and other selected constituents in the Rio Grande, Albuquerque Area, New Mexico: U.S. Geological Survey Open-File Report 96-126, 45 p.

Marzolf, G.R., Hart, R.J., and Stephens, D.W., 1998, Depth profiles of temperature, specific conductance, and oxygen concentration in Lake Powell, Arizona-Utah, 1992-95: U.S. Geological Survey Open-File Report 97-835, 119 p.

Mitko, K., and Bebek, M., 1999, ICP-OES determination of trace elements in salinated water: Atomic Spectroscopy, v. 20, p. 217-223.

National Park Service, 2004, A monitoring plan for the occurrence of hydrocarbon constituents in Lakes Powell, Mean, and Mohave - Arizona, Nevada, and Utah: Accessed September 12, 2012, at http://archive.org/details/ monitoringplanfo00nati

National Park Service, 2011, National Park Service Public Use Statistics Office-Annual Summary Report for 2011: Website, accessed February 22, 2012, at http://www.nature. nps.gov/stats/viewReport.cfm.

National Park Service, 2012, Glen Canyon National Recreation Area-Beach Monitoring Program: Website, accessed August 8, 2011, at http://www.nps.gov/glca/ naturescience/beachprogram.htm.

Radtke, D.B., 1997, National field manual for the collection of water-quality data-Bottom material samples: U.S. Geological Survey Techniques of Water Resources Investigations, Book 9, A8.
Roth, D.A., 1994, Ultratrace analysis of mercury and its distribution in some natural waters in the United States: Ft. Collins, Colorado State University, Ph.D. dissertation, 309 p.

Roth, D.A., Taylor, H.E., Domalgalski, J., Dileanis, P., Peart, D.B., Antweiler, R.C., and Alpers, C.N., 2001, Distribution of inorganic mercury in Sacramento River water and suspended colloidal sediment material: Archives of Environmental Contamination and Toxicology, v. 40, p. 161-172.

Schonauer, K., 2011, Determination of the presence of polycyclic aromatic hydrocarbons and trace elements in sediments and the potential for bioconcentration in biota at established sampling sites on Lake Powell: U.S. Geological Survey Website, accessed September 12, 2012, at http:// az.water.usgs.gov/projects/9671-E1D00/index.html.

Sea-Bird Electronics, Inc., 2012, Advancing the Science of Ocean Measurement: Website, accessed September 12, 2012, at http://www.seabird.com/.

Shelton, L.R., 1997, Field guide for collecting samples for analysis of volatile organic compounds in stream water for the National Water-Quality Assessment Program: U.S. Geological Survey Open-File Report 97-401, 14 p.

Skougstad, M.W., Fishman, M.J., Friedman, L.C., Erdman, D.E., and Duncan, S.S., 1979, Methods for the determination of inorganic substances in water and fluvial sediments: U.S. Geological Survey Techniques of WaterResources Investigations, Book 5, Chap. A1, 626 p.

Taylor, H.E., 2001, Inductively Coupled Plasma-Mass Spectrometry Practices and Techniques: San Diego, Academic Press, 294 p.

U.S. Environmental Protection Agency, 1999, Method 1664, Revision A-N-hexane extractable material (hem; oil and grease) and silica gel treated $\mathrm{N}$-hexane extractable material (Sgt-Hem; Non-Polar Material) by extraction and gravimetry: U.S. Environmental Protection Agency, Office of Water, EPA-821-R-98-002.

Vernieu, W.S., 2009, Historical physical and chemical data for water in Lake Powell and from Glen Canyon Dam Releases, Utah-Arizona, 1964-2008: U.S. Geological Survey Data Series 471, $23 \mathrm{p}$.

Wershaw, R.L., Fishman, M.J., Grabbe, R.R., and Lowe, L.E., 1987, Methods for the determination of organic substances in water and fluvial sediments: U.S. Geological Survey Techniques of Water-Resources Investigations, Book 5, Chap. A3, 80 p.

Wilde, F.D., and Radtke, D.B., 1998, National field manual for the collection of water-quality data-Field measurements: U.S. Geological Survey Techniques of Water-Resources Investigations, Book 9, Chap, A6, 114 p. 
This page intentionally left blank. 
Menlo Park Publishing Service Center, California Manuscript approved for publication November 9, 2012 Edited by Linda S. Rogers and Claire Landowski Layout and design by Judy Weathers 


\section{$\frac{\mathbb{2}}{30}$}

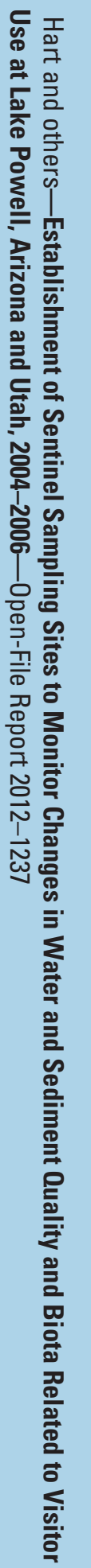

